\title{
A method to estimate cow potential and subsequent responses to energy and protein supply according to stage of lactation
}

\author{
J. B. Daniel, ${ }^{*} \dagger^{1}$ N. C. Friggens, ${ }^{*}$ H. Van Laar, $†$ C. P. Ferris, $\ddagger$ and D. Sauvant ${ }^{*}$ \\ *UMR Modélisation Systémique Appliquée aux Ruminants, INRA, AgroParisTech, Université Paris-Saclay, 75005 Paris, France \\ †Trouw Nutrition R\&D, PO Box 220, 5830 AE Boxmeer, the Netherlands \\ $\ddagger$ Agri-Food and Biosciences Institute, Hillsborough, Co. Down, BT26 6DR, United Kingdom
}

\section{ABSTRACT}

Milk responses to dietary change are influenced by the relative production level, that is, the distance between observed production and potential production. The closer the animal is to its potential, the smaller the expected response is to extra nutrients. Therefore, the aim of this work was to provide a method to quantify cow potential, to estimate subsequent responses to changes in nutrient supply. The observed efficiencies in net energy for lactation $\left(\mathrm{NE}_{\mathrm{L}}\right)$ and metabolizable protein (MP) are proposed as a basis to estimate the relative production level of the animal. The rationale for using $\mathrm{NE}_{\mathrm{L}}$ and MP efficiency (ratios of milk energy yield $/ \mathrm{NE}_{\mathrm{L}}$ above maintenance supply and milk protein yield/MP above maintenance supply) builds on the uniformity of the observed relationships between size of the milk responses and extra $\mathrm{NE}_{\mathrm{L}}$ supply and MP supply, when centered on a given efficiency. From there, a pivot nutritional situation where $\mathrm{MP}$ and $\mathrm{NE}_{\mathrm{L}}$ efficiency are 0.67 and 1.00, respectively, was defined, from which milk responses could be derived across animals varying in production potential. An implicit assumption of using response equations centered on reference efficiency pivots is that the size of the response to a fixed change in nutrient supply, relative to the pivot, is identical for animals with different production capacities. The proposed approach was evaluated with 2 independent data sets, where different dietary treatments were applied during the whole lactation. In these data sets, MP and $\mathrm{NE}_{\mathrm{L}}$ above maintenance supply were calculated weekly using the recently updated INRA Systali feed units system. Differences in $\mathrm{NE}_{\mathrm{L}}$ and MP supply above maintenance between the extreme dietary treatments were large, on average $667 \mathrm{~g}$ of $\mathrm{MP} / \mathrm{d}$ and $13 \mathrm{MJ}$ of $\mathrm{NE}_{\mathrm{L}} / \mathrm{d}(3.11 \mathrm{Mcal} / \mathrm{d})$ in the first data set, and $513 \mathrm{~g}$ of $\mathrm{MP} / \mathrm{d}$ and $29 \mathrm{MJ}$ of $\mathrm{NE}_{\mathrm{L}} / \mathrm{d}(6.93 \mathrm{Mcal} / \mathrm{d})$ for the

Received August 30, 2016.

Accepted January 11, 2017.

${ }^{1}$ Corresponding author: jean-baptiste.daniel@trouwnutrition.com second data set. Milk energy yield and milk component yields were predicted with root mean square prediction errors between 7.6 and $13.5 \%$ and concordance correlation coefficients between 0.784 and 0.934 , respectively. Assessed by the Akaike's information criterion, significant differences existed in the accuracy of prediction for milk energy yield and milk component yields between stages of lactation. However, the effects of stage of lactation were not consistent between data sets and, for most of the predicted variables, relatively small. We concluded that the pivot concept can be used to predict milk energy yield and milk component yields responses to dietary change with a good accuracy for diets that are substantially different and across all stages of lactation.

Key words: energy, protein, response, potential, milk composition

\section{INTRODUCTION}

In the context of an increasing demand for feed efficiency, the importance of accurately predicting animal responses to dietary changes is growing. In dairy cows, several quantitative reviews of the literature (Huhtanen and Nousiainen, 2012; Jensen et al., 2015; Daniel et al., 2016) or specific experiments (Brun-Lafleur et al., 2010) have generated equations that aim to predict milk yield or milk composition response to a dietary change. However, the accurate application of these equations on the farm requires an estimation of the production potential of the cows in question. For example, on a farm where the observed production is $30 \mathrm{~kg} / \mathrm{d}$ and the maximum production potential is also $30 \mathrm{~kg} / \mathrm{d}$, one expects zero response to an increase in feed quality. However, on a farm where the observed production is $30 \mathrm{~kg} / \mathrm{d}$ but the maximum production potential is 50 $\mathrm{kg} / \mathrm{d}$ one clearly expects a positive response to supplementation. Thus, a need exists to estimate the relative production level, that is, how far the animal is from its potential. Although the concept of potential appears useful, this notion is partly theoretical and often refers, 
as stated above, to the maximum production achievable in a nonlimiting environment (Neal and Thornley, 1983; Vetharaniam et al., 2003). In the context of predicting responses, a more useful definition would be the maximum production that can be achieved by a given animal in a standardized nutritional status. For the prediction of such a potential, herd-test day models, which include fixed effects (farm, gestation, length of dry-period, calving month, and so on) and random effects (genetic and permanent environment), represent a valuable approach (Leclerc, 2008). However, such models assume that the differences in nutritional environment are adequately captured by the fixed effect of farm, and for prediction purposes require information from the previous lactation. The objective of this work was to propose an alternative approach to determine the relative production level of the dairy cow and derive subsequent expected milk responses to changes in MP and $\mathrm{NE}_{\mathrm{L}}$ supply that could be easily applied on-farm. The MP and $\mathrm{NE}_{\mathrm{L}}$ efficiencies were proposed as status indicators to determine the relative production level, distance between the observed production, and the potential production; the rationale and quantitative basis for this choice are presented in the paper. The second objective of this work was to evaluate the method for predicting milk yield and milk component yields responses to changes in $\mathrm{MP}$ and $\mathrm{NE}_{\mathrm{L}}$ supply using 2 independent data sets.

\section{MATERIALS AND METHODS}

\section{Relationship Between Size of Milk Responses and $M P$ and $N E_{L}$ Efficiencies}

Milk responses to nutrient supply are usually modeled by quadratic or exponential equations. This reflects the widely established principle of diminishing returns (Brody, 1945). At the metabolic level, once nonproductive $\mathrm{MP}$ requirements and $\mathrm{NE}_{\mathrm{L}}$ maintenance requirement are discounted (see Sauvant et al., 2015a,b and Appendix 1 for details of calculations used in this study), the principle of diminishing returns to increasing $\mathrm{MP}$ and $\mathrm{NE}_{\mathrm{L}}$ supply is mostly explained by a change in partitioning. This is induced by a limitation of the mammary gland synthesis capacity. As $\mathrm{NE}_{\mathrm{L}}$ above maintenance increases, energy partitioning progressively shifts from milk to body lipid. Similarly, with increasing MP supply above maintenance, nitrogen partitioning progressively shifts from milk protein to urinary nitrogen. These effects were observed using milk protein and energy yield equations developed by meta-analysis (Figure 1; Daniel et al., 2016). In the illustrated example, the marginal MP efficiency or par- titioning (i.e., the slopes of the curves in Figure 1a) decreases from 0.38 to 0.19 when MP supply increases from 993 to 1,493 g/d. A further increase from 1,493 to $1,893 \mathrm{~g} / \mathrm{d}$ results to a decrease in marginal MP efficiency from 0.19 to 0.04 . The consequence of this partitioning is that the overall global MP efficiency $(\mathbf{M P e f f}=$ milk protein yield/MP supply above maintenance) decreases from 0.86 to 0.67 (when MP supply above maintenance increases from 993 to $1,493 \mathrm{~g} / \mathrm{d}$ ) and from 0.67 to 0.55 (when MP supply above maintenance increases from 1,493 to $1,893 \mathrm{~g} / \mathrm{d}$ ). With respect to energy (Figure $1 \mathrm{~b}$ ), a similar relationship was found between marginal $\mathrm{NE}_{\mathrm{L}}$ efficiency in milk and the global $\mathrm{NE}_{\mathrm{L}}$ efficiency $\left(\mathbf{N E}_{\mathbf{L}} \mathbf{e f f}\right.$ $=$ milk energy $/ \mathrm{NE}_{\mathrm{L}}$ supply above maintenance). When $\mathrm{NE}_{\mathrm{L}}$ supply increases from 65 to $95 \mathrm{MJ} / \mathrm{d}$ (15.54 to $22.71 \mathrm{Mcal} / \mathrm{d}$ ) and from 95 to $125 \mathrm{MJ} / \mathrm{d}$ (22.71 to 29.88 Mcal/d), the marginal $\mathrm{NE}_{\mathrm{L}}$ efficiency decreases from 0.27 to 0.17 and from 0.17 to 0.06 , respectively, and global $\mathrm{NE}_{\mathrm{L}}$ eff decreases from 1.36 to 1.00 and from 1.00 to 0.79 , respectively. With these positive relationships observed between global and marginal efficiencies, we hypothesized that MP and $\mathrm{NE}_{\mathrm{L}}$ efficiencies could provide a mean to estimate the relative production level of the animal (i.e., how far the animal is from potential), and thereby provide the basis for predicting response to dietary changes in $\mathrm{MP}$ and $\mathrm{NE}_{\mathrm{L}}$. It should be noted that the potential here does not refer to genetic potential, in the sense of maximum production achieved in a truly nonlimiting environment; instead, it refers to cow performance on a standardized nutritional situation within its given environment. Therefore, this notion of potential includes current and past environmental effects on the cow production capacity.

\section{Estimation of Pivots from Which to Predict Milk Responses}

Using data collected from a large number of experiments [see Daniel et al. (2016) for the full list of references], Figure 2 shows the relationships between milk protein yield and MP supply above maintenance (panel a) and between milk energy and $\mathrm{NE}_{\mathrm{L}}$ supply above maintenance (panel b). On Figure 2, the dashed lines represent the global efficiencies MPeff $=0.67$ (panel a) and $\mathrm{NE}_{\mathrm{L}}$ eff $=1$ (panel b). These efficiency lines intersect most of the curves within the range of data (i.e., from low- to high-producing animals); therefore, it was decided to use the fixed efficiency values as a reference point, or pivot, that is relevant across the whole range of production levels. In predicting responses, the reference efficiency line can be seen as being a rail along which the response curve would move up or down according to animal potential. This principle, already 
suggested by Huhtanen and Nousiainen (2012), extends the applicability of response equations by including the effect of animal production capacity. The chosen values of efficiency for the pivot are consistent with established feeding system values for protein (NRC, 2001; Sauvant et al., 2015a). For energy, $\mathrm{NE}_{\mathrm{L}}$ eff $=1.00$ was chosen because it is equivalent to zero energy balance and this value is very close to the average found in a data set of 825 treatment means (0.99; Daniel et al., 2016). In Figure 2c and d, intersections between the reference efficiency lines (panel c, MPeff $=0.67$; panel $\mathrm{d}, \mathrm{NE}_{\mathrm{L}}$ eff $=1.00$ ) and each of the 3 response curves representing low-, medium-, and high-producing animals on the $\mathrm{x}$-axis, the levels of MP and $\mathrm{NE}_{\mathrm{L}}$ supply above maintenance at the reference situation for a given type of animal (MPpivot and $\mathbf{N E}_{\mathbf{L}}$ pivot, respectively). These levels are called pivot because they are the central points around which the response curve can be applied. Using the MPpivot, the milk protein yield response ( $\triangle \mathrm{MPY})$ can then be written as follows (assuming changes in $\mathrm{NE}_{\mathrm{L}}$ are zero):

$$
\begin{gathered}
\Delta \text { MPY }(\mathrm{g} / \mathrm{d})=\text { MPY }- \text { MPYpivot }= \\
\text { 0.19(MP }- \text { MPpivot })-0.000193(\mathrm{MP}-\mathrm{MPpivot})^{2},
\end{gathered}
$$

where MPY is the observed milk protein yield $(\mathrm{g} / \mathrm{d})$, MPYpivot $=0.67 \times$ MPpivot, and MP is the observed MP supply above maintenance $(\mathrm{g} / \mathrm{d})$. The coefficients 0.19 and 0.000193 are derived from the meta-analysis of Daniel et al. (2016). As MPYpivot is calculated from

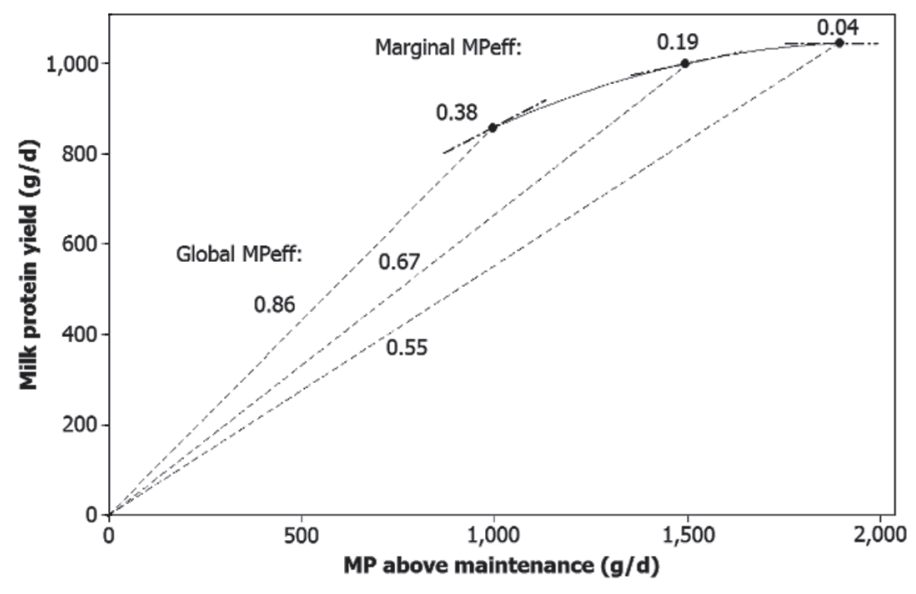

MPpivot, the only unknown variable in this equation is MPpivot. This value can be calculated from any pair of observed values of MPY and MP. Once this pivot has been calculated, the milk protein yield response to any dietary MP changes can be predicted. This is true under the assumption that MPpivot do not vary with dietary MP changes for that particular animal and at that particular time.

A similar type of equation describes the milk energy response $(\triangle \mathrm{MEY})$ to $\mathrm{NE}_{\mathrm{L}}$ supply (assuming changes in MP are zero):

$$
\begin{gathered}
\Delta \text { MEY }(\mathrm{MJ} / \mathrm{d})=\mathrm{MEY}-\mathrm{MEY} \text { pivot }= \\
0.166\left(\mathrm{NE}_{\mathrm{L}}-\mathrm{NE}_{\mathrm{L}} \text { pivot }\right)-0.0018\left(\mathrm{NE}_{\mathrm{L}}-\mathrm{NE}_{\mathrm{L}} \text { pivot }\right)^{2},
\end{gathered}
$$

where MEY is the observed milk energy yield $(\mathrm{MJ} / \mathrm{d})$, MEYpivot $=1 \times \mathrm{NE}_{\mathrm{L}}$ pivot, and $\mathrm{NE}_{\mathrm{L}}$ is the observed $\mathrm{NE}_{\mathrm{L}}$ supply above maintenance $(\mathrm{g} / \mathrm{d})$. As for equation 1 , coefficients 0.166 and 0.0018 are derived from the meta-analysis of Daniel et al. (2016). An implicit assumption of using response equations centered on reference efficiency pivots is that, when global MPeff $=0.67$ and global $\mathrm{NE}_{\mathrm{L}}$ eff $=1.00$, the size of the response to extra $\mathrm{MP}$ or $\mathrm{NE}_{\mathrm{L}}$ supply is identical regardless of differences in animal production capacity (Figure 2c and d). By expressing $\mathrm{NE}_{\mathrm{L}}$ and $\mathrm{MP}$ supply relative to the efficiency pivots, the effects of protein and energy supply on performance are standardized, which means that they can be dissociated from performance differences due to animal production capacity, providing animals

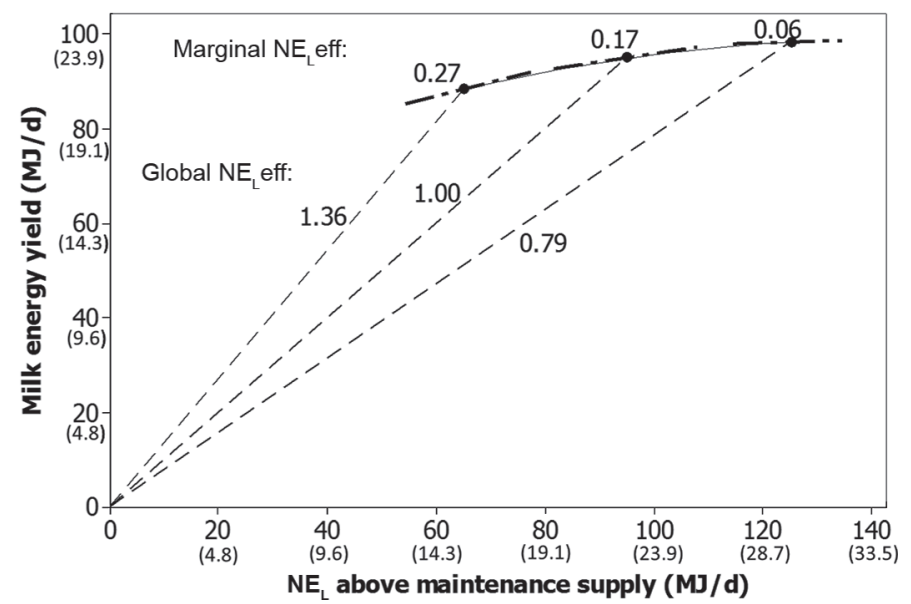

Figure 1. Average response curves of milk protein yield to changing MP supply above maintenance and milk energy yield to $\mathrm{NE}_{\mathrm{L}}$ supply above maintenance (equations from Daniel et al., 2016). The global MP and $\mathrm{NE}_{\mathrm{L}}$ efficiencies (MPeff and $\mathrm{NE}_{\mathrm{L}}$ eff; i.e., the ratio between milk protein yield and MP above maintenance and between milk energy yield and $\mathrm{NE}_{\mathrm{L}}$ above maintenance, respectively) are represented with dashed lines. The marginal MPeff and $\mathrm{NE}_{\mathrm{L}}$ eff are the derivative of the response curves and indicate the proportion of protein and energy secreted in milk per extra unit supply of MP and $\mathrm{NE}_{\mathrm{L}}$, respectively. In parentheses, energy values are reported in Mcal/d. 
are at the same physiological status (parity, lactation stage, and so on). Aspects related to stage of lactation are discussed later in the paper.

For the sake of simplicity, energy and protein were represented independently in Figures 1 and 2; however, $\mathrm{NE}_{\mathrm{L}}$ supply influences milk protein yield response and MP supply influences milk energy response (Daniel et al., 2016). A more comprehensive representation of milk protein and energy responses is presented in Figure 3 for an average group of animals producing at a level equivalent to pivots of $1,000 \mathrm{~g} / \mathrm{d}$ of milk protein and $95 \mathrm{MJ} / \mathrm{d}(22.71 \mathrm{Mcal} / \mathrm{d})$ of milk energy. The effect of $\mathrm{NE}_{\mathrm{L}}$ supply on milk protein yield (Figure $3 \mathrm{~b}$ ) and of MP supply on milk energy yield (Figure 3a) are shown by vertical displacement of the lines. The straight line
MPeff $=0.67$ crosses each level of $\mathrm{NE}_{\mathrm{L}}$ supply above maintenance represented on the Figure 3a, indicating that multiple combination of $\mathrm{NE}_{\mathrm{L}}$ and $\mathrm{MP}$ supplies can result in MPeff $=0.67$. This is because, independently from MP supply, an increase in $\mathrm{NE}_{\mathrm{L}}$ supply positively influences milk protein yield, thereby increasing MPeff. Similarly, independently from $\mathrm{NE}_{\mathrm{L}}$ supply, extra $\mathrm{MP}$ supply increases milk energy yield, which increases $\mathrm{NE}_{\mathrm{L}}$ eff, and, thus, multiple combinations of $\mathrm{NE}_{\mathrm{L}}$ and $\mathrm{MP}$ supplies can result in $\mathrm{NE}_{\mathrm{L}}$ eff $=1.00$. Nevertheless, only one combination simultaneously gives MPeff $=0.67$ and $\mathrm{NE}_{\mathrm{L}}$ eff $=1$. In the case of the example illustrated in Figure 3, MPeff $=0.67$ and $\mathrm{NE}_{\mathrm{L}}$ eff $=1.00$ are simultaneously achieved when MPpivot $=1,493$ $\mathrm{g} / \mathrm{d}$ and $\mathrm{NE}_{\mathrm{L}}$ pivot $=95 \mathrm{MJ} / \mathrm{d}(22.71 \mathrm{Mcal} / \mathrm{d})$. Because
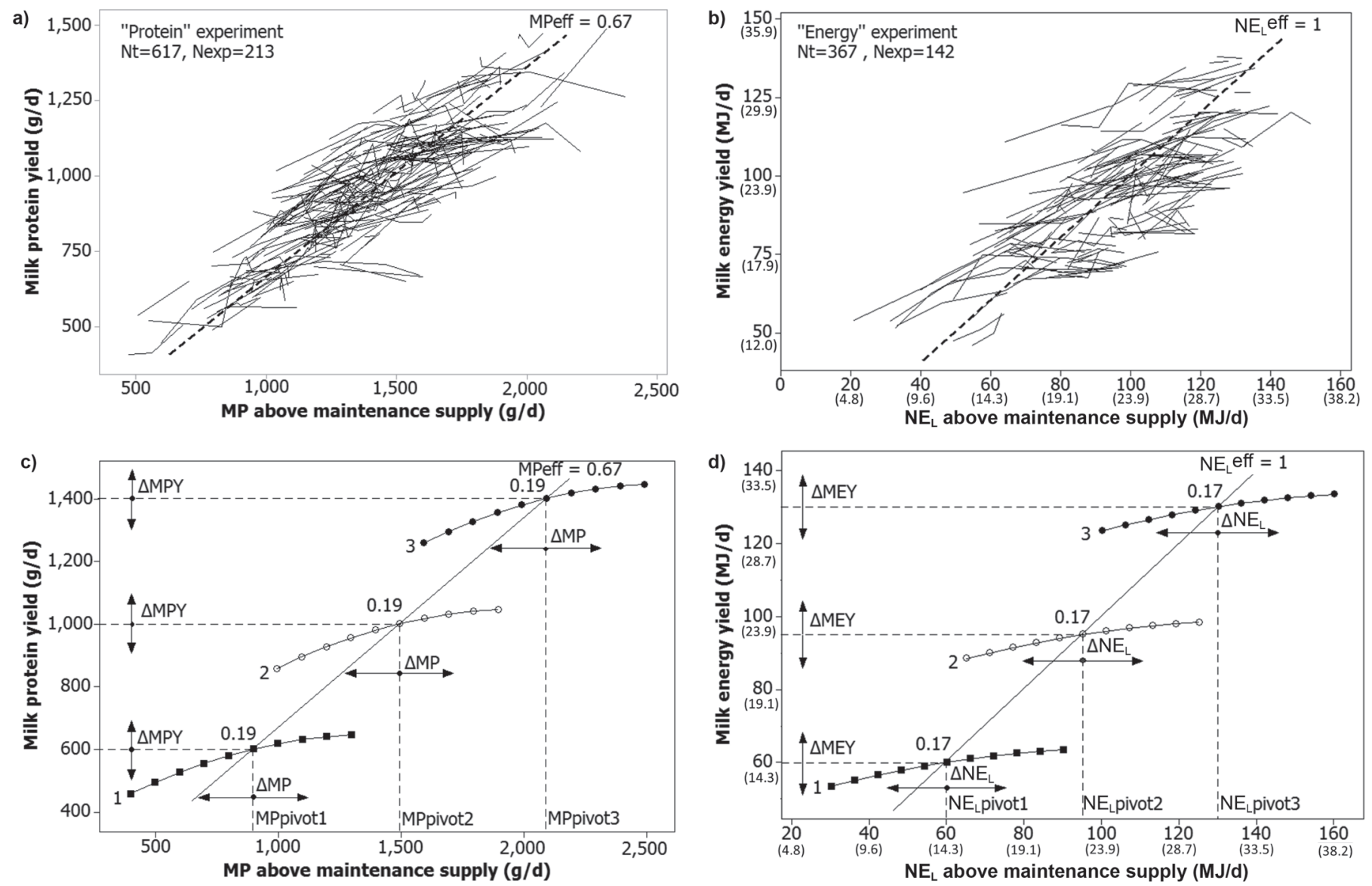

Figure 2. (a) The relationship between milk protein yield and MP above maintenance supply observed with experiments where MP supply was the main factor of variation between treatments. The global MP efficiency (MPeff) of 0.67 is represented by the dashed line. Each solid line represents 1 experiment group (Nexp $=213$ ) including 617 treatments $(\mathrm{Nt})$. (b) The relationship between milk energy yield and $\mathrm{NE}_{\mathrm{L}}$ above maintenance supply observed with experiments where $\mathrm{NE}_{\mathrm{L}}$ supply was the main factor of variation between treatments. The global NE $\mathrm{E}_{\mathrm{L}}$ efficiency $\left(\mathrm{NE}_{\mathrm{L}} \mathrm{eff}\right)$ of 1 is represented by the dashed line. Each solid line represents 1 experiment group $($ Nexp $=142)$ including 367 treatments $(\mathrm{Nt})$. (c) Milk protein yield (MPY) response to MP supply above maintenance for 3 groups of animals with low $(\mathbf{\square})$, medium $(O)$, and high $(\bullet)$ production levels. The levels of MP supply above maintenance required when global MPeff is 0.67 are called MPpivot. (d) Milk energy yield (MEY) response to $\mathrm{NE}_{\mathrm{L}}$ supply above maintenance for 3 groups of animals with low $(\boldsymbol{\square})$, medium $(O)$, and high $(\bullet)$ production levels. The level of $\mathrm{NE}_{\mathrm{L}}$ supply above maintenance required when global $\mathrm{NE}_{\mathrm{L}}$ eff is 1 is called $\mathrm{NE}_{\mathrm{L}}$ pivot. Equations from Daniel et al. (2016). In parentheses, energy values are reported in Mcal/d. 
of the influence of both $\mathrm{NE}_{\mathrm{L}}$ and MP supply on MPpivot and $\mathrm{NE}_{\mathrm{L}}$ pivot, the pivots need to be calculated by simultaneously taking into account the milk energy and protein responses. Incorporating the $\mathrm{NE}_{\mathrm{L}}$ effect (Daniel et al., 2016) in equation 1 and the MP effect in equation 2 , we have

$$
\begin{gathered}
\text { MPY }- \text { MPYpivot }(\mathrm{g} / \mathrm{d})=0.19(\mathrm{MP}-\mathrm{MPpivot}) \\
-0.000193(\mathrm{MP}-\mathrm{MPpivot})^{2}+3.137\left(\mathrm{NE}_{\mathrm{L}}-\mathrm{NE}_{\mathrm{L}} \text { pivot }\right) \\
-0.021\left(\mathrm{NE}_{\mathrm{L}}-\mathrm{NE}_{\mathrm{L}} \text { pivot }\right)^{2},
\end{gathered}
$$

with MPYpivot $=0.67 \times$ MPpivot, and

$$
\begin{gathered}
\text { MEY }- \text { MEYpivot }(\mathrm{MJ} / \mathrm{d})=0.166\left(\mathrm{NE}_{\mathrm{L}}-\mathrm{NE}_{\mathrm{L}} \text { pivot }\right) \\
-0.0018\left(\mathrm{NE}_{\mathrm{L}}-\mathrm{NE}_{\mathrm{L}} \text { pivot }\right)^{2}+0.015(\mathrm{MP}-\mathrm{MPpivot}) \\
-0.000017(\mathrm{MP}-\mathrm{MPpivot})^{2},
\end{gathered}
$$

with MEYpivot $=1 \times \mathrm{NE}_{\mathrm{L}}$ pivot. This is a system of 2 equations with 2 unknowns (MPpivot and $\mathrm{NE}_{\mathrm{L}}$ pivot), which can in principle be solved algebraically when MPY, MEY, MP, and $\mathrm{NE}_{\mathrm{L}}$ are observed. However, because of the quadratic nature of the equations, mathematically 4 possible solutions exist for the system. An optimization procedure was developed to handle this aspect (details are presented in Appendix 2). With this approach, pivot values calculated are uniquely defined, with MPpivot and $\mathrm{NE}_{\mathrm{L}}$ pivot being the levels of MP and $\mathrm{NE}_{\mathrm{L}}$ supplies above maintenance, resulting in global MPeff $=0.67$ and global $\mathrm{NE}_{\mathrm{L}}$ eff $=1.00$. Equations 3 and 4 are therefore used for 2 purposes, the first being to calculate the pivots from a given observation when

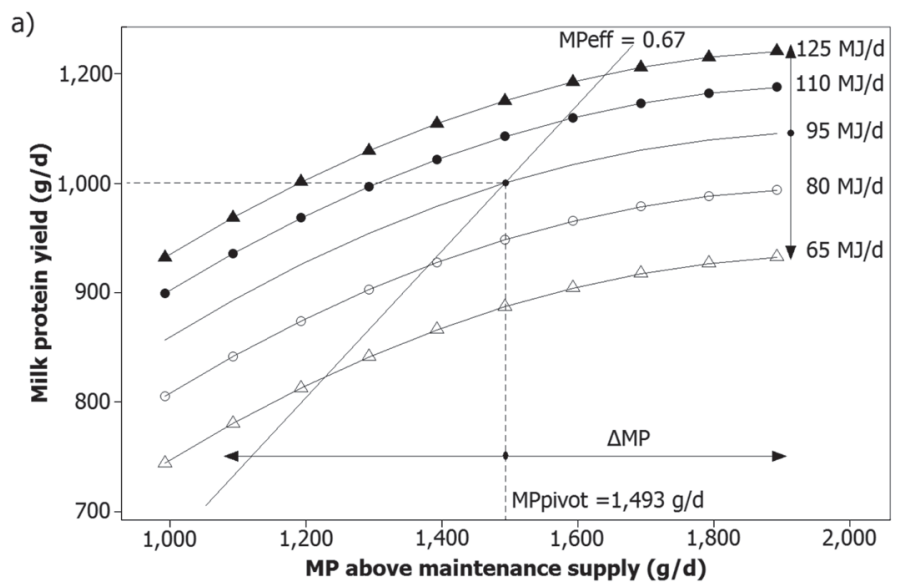

the supplies in $\mathrm{MP}$ and $\mathrm{NE}_{\mathrm{L}}$ and the actual production are known. For that purpose, the appropriate response curve, corresponding to the production potential of that animal, is associated with the observation. Second, once MPpivot and $\mathrm{NE}_{\mathrm{L}}$ pivot are known, equations 3 and 4 can be applied to predict milk protein and energy yield responses to nutritional manipulation (i.e., new inputs of $\mathrm{MP}$ and $\mathrm{NE}_{\mathrm{L}}$ supply).

Given MPpivot and $\mathrm{NE}_{\mathrm{L}}$ pivot, pivot values can also be calculated for milk fat yield and milk lactose yield. For that, the distances between observed MP and MPpivot and between observed $\mathrm{NE}_{\mathrm{L}}$ and $\mathrm{NE}_{\mathrm{L}}$ pivot are used to estimate the distances between observed milk fat yield and pivot milk fat yield and between observed milk lactose yield and pivot milk lactose yield:

$$
\begin{gathered}
\Delta \mathrm{MFY}=0.159(\mathrm{MP}-\mathrm{MPpivot})-0.000238(\mathrm{MP} \\
-\mathrm{MPpivot})^{2}+0.611\left(\mathrm{NE}_{\mathrm{L}}-\mathrm{NE}_{\mathrm{L}} \text { pivot }\right) \\
-0.021\left(\mathrm{NE}_{\mathrm{L}}-\mathrm{NE}_{\mathrm{L}} \text { pivot }\right)^{2}
\end{gathered}
$$

and

$$
\begin{gathered}
\Delta \mathrm{MLY}=0.283(\mathrm{MP}-\mathrm{MPpivot})-0.000172(\mathrm{MP} \\
-\mathrm{MPpivot})^{2}+4.076\left(\mathrm{NE}_{\mathrm{L}}-\mathrm{NE}_{\mathrm{L}} \text { pivot }\right),
\end{gathered}
$$

where $\triangle \mathrm{MFY}$ and $\triangle \mathrm{MLY}$ are the distances between observed and pivot production for milk fat yield and milk lactose yield, respectively. Distances are estimated using response equations to change in $\mathrm{NE}_{\mathrm{L}}$ and $\mathrm{MP}$ supply developed in Daniel et al. (2016). The actual pivot values for milk fat yield (MFYpivot) and milk

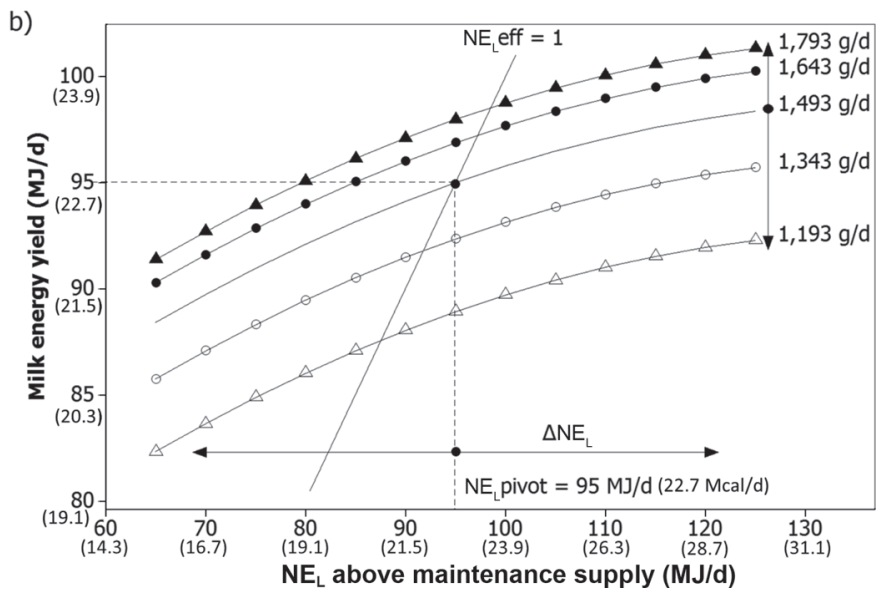

Figure 3. Average milk protein yield (a) and milk energy yield (b) responses to change in MP and $\mathrm{NE}_{\mathrm{L}}$ supply for a group of animals producing $1,000 \mathrm{~g} / \mathrm{d}$ of protein and $95 \mathrm{MJ} / \mathrm{d}(22.71 \mathrm{Mcal} / \mathrm{d})$ of energy at pivots. MPpivot = level of MP above maintenance supply for which MP efficiency (MPeff) is 0.67 and $\mathrm{NE}_{\mathrm{L}}$ efficiency is $1 ; \mathrm{NE}_{\mathrm{L}}$ pivot $=$ level of $\mathrm{NE}_{\mathrm{L}}$ above maintenance supply for which $\mathrm{NE}_{\mathrm{L}}$ efficiency (NE $\mathrm{N}_{\mathrm{L}}$ eff) is 1 and MP efficiency is 0.67. Figure 3a was adapted from Daniel et al. (2016). In parentheses, energy values are reported in Mcal/d. 
lactose yield (MLYpivot) can then be calculated by subtracting $\triangle \mathrm{MFY}$ from the observed milk fat yield (MFY), and $\triangle \mathrm{MLY}$ from the observed milk lactose yield (MLY):

$$
\text { MFYpivot }(\mathrm{g} / \mathrm{d})=\operatorname{MFY}-\Delta \mathrm{MFY}
$$

and

$$
\operatorname{MLYpivot}(\mathrm{g} / \mathrm{d})=\mathrm{MLY}-\Delta \mathrm{MLY} \text {. }
$$

With these pivots, the consequences of changes from observed MP and $\mathrm{NE}_{\mathrm{L}}$ supply on milk fat yield and milk lactose yield can be estimated. Given the assumption about fixed efficiency referencing production level relative to potential, we now have a system to predict milk energy yield and milk component yield responses for animals of different potential at that time.

\section{Implication of Stage of Lactation on Pivot Values}

The choice of reference values for MPeff and $\mathrm{NE}_{\mathrm{L}}$ eff was derived using a data set mainly based on observations in mid lactation $(\mathrm{n}=819$, average $\pm \mathrm{SD}=131 \pm$ 51 DIM; Daniel et al., 2016); however, a clear effect of stage of lactation was observed on MPeff and $\mathrm{NE}_{\mathrm{L}}$ eff, even when the ration composition did not change. These effects are illustrated in Figure 4, which shows data for the least constraining nutritional treatments from the 2 data sets used for model evaluation (Friggens et al., 1998; Law et al., 2009). In both experiments the ration remained constant throughout lactation. For protein, the calculation of MP above maintenance is adjusted for an estimation of body protein change scaled on energy balance (EB; Sauvant et al., 2015a).
Thus, in theory, nitrogen from MP can only be partitioned into milk or urine. Assuming that the efficiency of biochemical transformation of $1 \mathrm{~g}$ of MP into milk protein does not change with time, the observed linear decreasing MP efficiency throughout lactation is the result of a progressive shift in nitrogen partitioning from milk toward urine. For energy, the effect of stage of lactation observed on $\mathrm{NE}_{\mathrm{L}}$ eff is essentially the result of homeorhetic regulation. The shape of the $\mathrm{NE}_{\mathrm{L}}$ eff curve reflects the well-established patterns of energy balance (i.e., changing patterns of body reserve mobilization and accretion) as the animal progresses through lactation (Friggens et al., 2007). The high efficiency $(>1)$ in early lactation reflects body energy mobilization, and the low efficiency $(<1)$ in late lactation indicates body energy deposition; therefore, changes in $\mathrm{NE}_{\mathrm{L}}$ eff with stage of lactation are also the consequences of changes in energy partitioning. These lactation profiles of changing $\mathrm{MP}$ and $\mathrm{NE}_{\mathrm{L}}$ efficiencies have consequences on the expected size of responses to dietary changes. As illustrated in Figure 1, the size of the response decreases with decreasing MPeff and $\mathrm{NE}_{\mathrm{L}}$ eff. Thus, an implicit assumption of using fixed reference MPeff and $\mathrm{NE}_{\mathrm{L}}$ eff as pivots throughout lactation is that because of the high efficiencies observed in early lactation, and the low efficiency observed in late lactation, the size of the response in milk will be greater in early than in late lactation. This is consistent with the animal changing priority of nutrient partitioning through lactation (Bauman and Currie, 1980). Accordingly, fixed pivots of MPeff $=0.67$ and $\mathrm{NE}_{\mathrm{L}}$ eff $=1.00$ are used independently of the lactation stage. Combining this consideration with the rationale presented above, we suggest that milk responses can be predicted at any stage of the lactation.
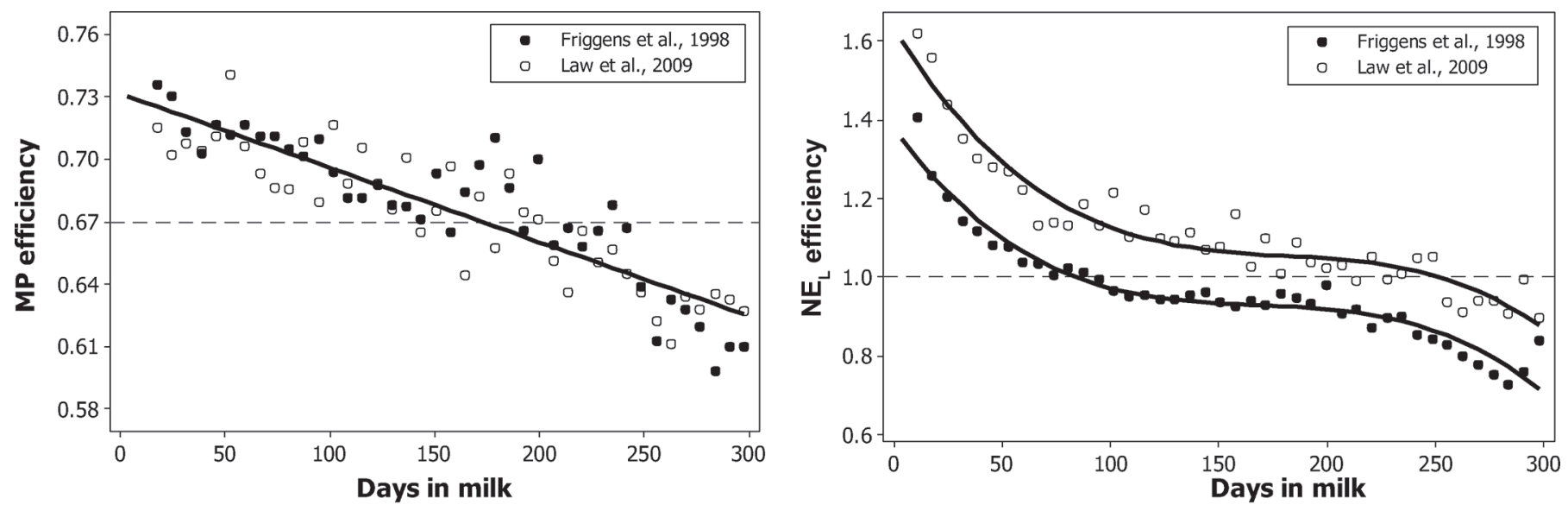

Figure 4. Metabolizable protein and $\mathrm{NE}_{\mathrm{L}}$ efficiency relative to DIM calculated for the treatment with $59 \%$ concentrate (DM basis) in Friggens et al. (1998) and for the treatment with 17.3\% CP (DM basis) in Law et al. (2009). 
Table 1. Intake, milk production, and calculated nutritional values with INRA Systali feed unit system for weekly data of Law et al. (2009); means $( \pm \mathrm{SD})$ are for cows that received the same dietary treatment throughout the entire lactation ${ }^{1}$

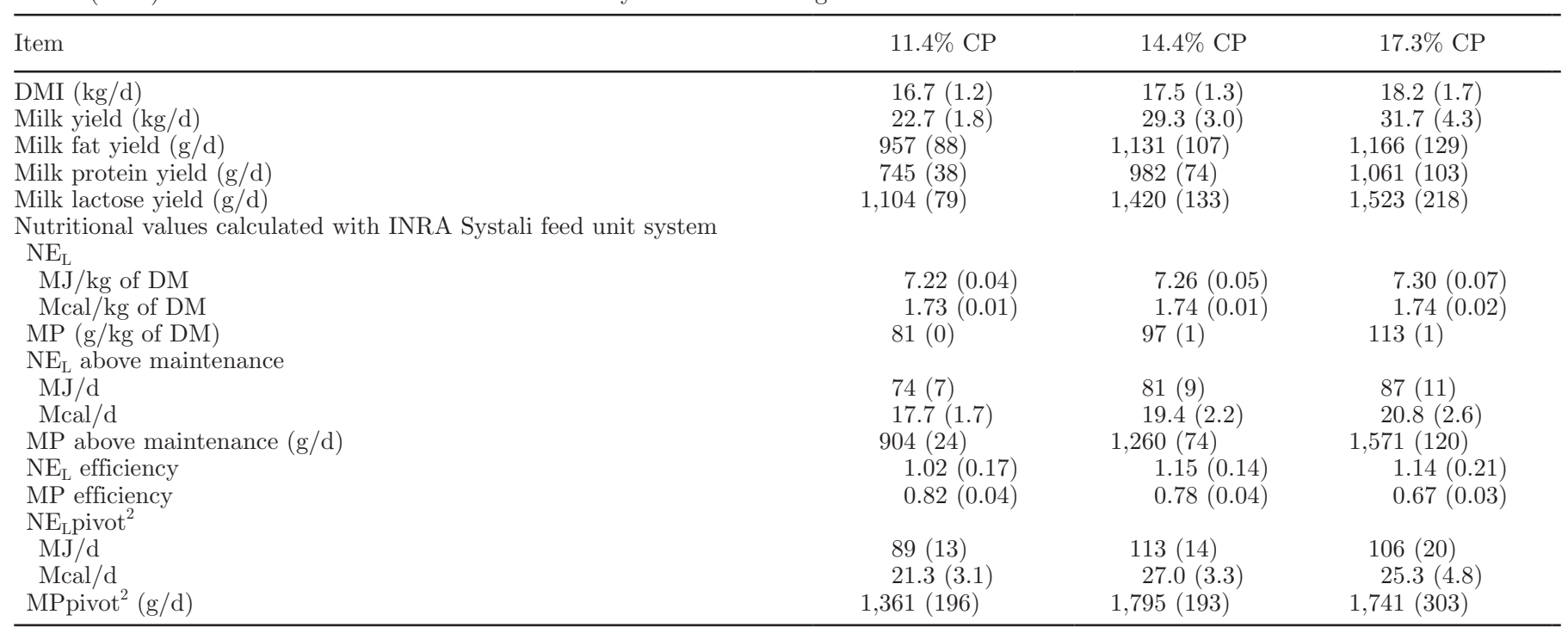

${ }^{1}$ Means of 43 weekly means are presented. Number of cows per treatment were 16, 15, and 16 for $11.4,14.4$, and $17.3 \%$ CP, respectively. ${ }^{2} \mathrm{NE}_{\mathrm{L}}$ pivot $=$ level of $\mathrm{NE}_{\mathrm{L}}$ above maintenance supply for which $\mathrm{NE}_{\mathrm{L}}$ efficiency is 1 and $\mathrm{MP}$ efficiency is 0.67 ; MPpivot = level of MP above maintenance supply for which MP efficiency is 0.67 and $\mathrm{NE}_{\mathrm{L}}$ efficiency is 1 .

\section{Model Evaluation}

The original data from 2 entire lactation experiments with large differences in either $\mathrm{MP}$ or $\mathrm{NE}_{\mathrm{L}}$ supply between treatments were selected to evaluate the accuracy of the method presented to predict milk energy yield and milk component yields. Briefly, the first experiment (Friggens et al., 1998) was characterized by 2 levels of dietary concentrate (27 and 59\%, DM basis) offered to 24 multiparous Holstein cows in a full $2 \times 2$ change-over design with control treatments. The experiment of Law et al. (2009) involved 3 rations with different CP content (11.4, 14.4, and 17.3\%, DM basis) fed to 90 Holstein cows ( $50 \%$ primiparous) in a $3 \times 2$ change-over design, where half of the animals of each treatment were allocated to an alternative dietary $\mathrm{CP}$ content at mid lactation. For the purpose of evaluating model predictions, weekly average values of each treatment group were used in both experiments. In Friggens et al. (1998), a total of 168 weekly average values were used (42 weekly averages $\times 4$ dietary treatments); in Law et al. (2009), a total of 258 weekly average values were used (43 weekly averages $\times 6$ dietary treatments). From those data, dietary $\mathrm{NE}_{\mathrm{L}}$ and $\mathrm{MP}$ contents were calculated using the recently updated INRA Systali feed units system (Sauvant and Nozière, 2016). Supplies of $\mathrm{NE}_{\mathrm{L}}$ and MP above maintenance were then calculated by subtracting nonproductive MP requirements (Sauvant et al., 2015a) and $\mathrm{NE}_{\mathrm{L}}$ maintenance requirement
(Sauvant et al., 2015b) from total supplies. A minor modification was proposed in the calculation of MP above maintenance relative to Sauvant et al. (2015a). In the original publication, the body protein balance (g/d), used to adjust MP above maintenance, was estimated as a constant ratio of $\mathrm{EB}$ (equal to $4.479 \times \mathrm{EB}$, equivalent to a protein content of BW change of $166 \mathrm{~g} /$ $\mathrm{kg})$. This approach of using a constant ratio is also used in other feed unit systems (NRC, 2001; Thomas, 2004; Volden, 2011). This suggests that the composition of the gain or loss (ratio fat: protein) throughout the lactation is constant, despite evidence that this is not the case (Belyea et al., 1978; Gibb et al., 1992; Tamminga et al., 1997). To improve this, published experiments (Belyea et al., 1978; Martin and Ehle, 1986; Chilliard et al., 1991; McGuffey et al., 1991; Gibb et al., 1992; Andrew et al., 1994; Komaragiri and Erdman, 1997; Komaragiri et al., 1998) with measured body lipid and protein changes relative to stage of lactation were used. From these experiments the following empirical relationship between body protein balance and EB $(\mathrm{MJ} / \mathrm{d})$ was obtained:

$$
\begin{gathered}
\text { Body protein balance }(\mathrm{g} / \mathrm{d})= \\
\left(21.2+56.04 \times e^{-0.033 \text { DIM }}\right)(\mathrm{EB} / 7.37),
\end{gathered}
$$

where $e$ is the exponential. This relationship simulates an increasing fat-to-protein ratio within the mobilized 
tissue as DIM increases. The final $\mathrm{NE}_{\mathrm{L}}$ and MP above maintenance values, calculated for the 2 experiments are shown in Tables 1 and 2 .

To evaluate the use of the pivot values for protein and energy to predict milk responses, weekly $\mathrm{NE}_{\mathrm{L}}$ and MP supplies above maintenance were used together with milk energy and protein yields to calculate pivot values for $\mathrm{MP}$ and $\mathrm{NE}_{\mathrm{L}}$. The MPpivot and $\mathrm{NE}_{\mathrm{L}}$ pivot were calculated for each week using the mean of the data from one treatment and applied together with the response equations to predict milk energy yield and milk components yields of the other treatments. In Friggens et al. (1998), the treatment with high concentrate (59\%, DM basis) was first used to calculate pivots, and comparisons of model predictions with data were performed with the rest of the treatments. In that case, a total of 126 comparisons of weekly averages were made [42 weekly averages $\times(4-1)$ dietary treatments]. Further, because the treatment used to calculate the pivots could potentially influence the accuracy of the prediction, the procedure was repeated using the treatment with a low concentrate level (27\%, DM basis) to calculate the pivots and predict milk energy yield and milk component yields of the other treatments. Thus, in total, 252 comparisons of weekly averages were made (126 with pivot calculated from the high-concentrate treatment and 126 with pivot calculated from the lowconcentrate treatment). The same approach was applied to the experiment of Law et al. (2009), where the pivots were calculated 3 times: from the treatment with low $\mathrm{CP}$ content $[215$ weekly averages $=43$ weekly averages $\times(6-1)$ dietary treatments], with medium $\mathrm{CP}$ content (215 weekly averages), and with high CP content (215 weekly averages). For Law et al. (2009), 645 comparisons of weekly averages were made.

For this evaluation, the quality of the independent predictions was evaluated using the concordance correlation coefficient (CCC), calculated as described in Lin (1989), and the root mean square prediction error (RMSPE), computed as previously described (Theil, 1966; Bibby and Toutenburg, 1977). The RMSPE can be decomposed into error due to overall bias, error due to deviation of the regression slope from unity, and error due to the disturbance (random error; Bibby and Toutenburg, 1977). Finally, the effects of stage of lactation on the quality of the model prediction for milk energy yield and milk component yields were evaluated with the corrected Akaike's information criterion (AICc). For that purpose, 3 groups of stage of lactation were created: early lactation ( $<15 \mathrm{wk}$ in milk), mid lactation $(\geq 15$ to $<30 \mathrm{wk})$, and late lactation $(\geq 30 \mathrm{wk}$ in milk). Based on these 3 groups, 2 dummy variables were created: M (1 for mid lactation, 0 for early and late lactation) and $\mathrm{L}$ (1 for late lactation, 0 for early and mid lactation). To evaluate the effect of stage of lactation, a reduced model was compared with a full model using PROC REG (SAS Institute Inc., Cary, $\mathrm{NC})$. The reduced model was

Table 2. Intake, milk production, and calculated nutritional values with INRA Systali feed unit system for weekly data of Friggens et al. (1998); means $( \pm \mathrm{SD})$ are for cows that received the same dietary treatment throughout the entire lactation ${ }^{1}$

\begin{tabular}{|c|c|c|}
\hline Item & $27 \%$ Concentrate & $59 \%$ Concentrate \\
\hline DMI $(\mathrm{kg} / \mathrm{d})$ & $16.1(1.2)$ & $20.4(1.7)$ \\
\hline Milk yield $(\mathrm{kg} / \mathrm{d})$ & $24.2(3.5)$ & $31.0(6.9)$ \\
\hline Milk fat yield $(\mathrm{g} / \mathrm{d})$ & $1,075(176)$ & $1,182(263)$ \\
\hline Milk protein yield $(\mathrm{g} / \mathrm{d})$ & $747(93)$ & $990(194)$ \\
\hline Milk lactose yield $(\mathrm{g} / \mathrm{d})$ & $1,074(177)$ & $1,477(356)$ \\
\hline \multicolumn{3}{|c|}{$\begin{array}{l}\text { Nutritional values calculated with INRA Systali feed unit system } \\
\mathrm{NE}_{\mathrm{L}}\end{array}$} \\
\hline $\mathrm{MJ} / \mathrm{kg}$ of DM & $7.39(0.04)$ & $7.31(0.06)$; \\
\hline Mcal/kg of DM & $1.77(0.01)$ & $1.75(0.01)$ \\
\hline $\mathrm{MP}(\mathrm{g} / \mathrm{kg}$ of $\mathrm{DM})$ & $82(1)$ & $100(1)$ \\
\hline \multicolumn{3}{|l|}{$\mathrm{NE}_{\mathrm{L}}$ above maintenance } \\
\hline $\mathrm{MJ} / \mathrm{d}$ & $69(8)$ & $98(13)$ \\
\hline Mcal/d & $16.5(1.9)$ & $23.4(3.1)$ \\
\hline MP above maintenance $(\mathrm{g} / \mathrm{d})$ & $929(73)$ & $1,442(217)$ \\
\hline $\mathrm{NE}_{\mathrm{L}}$ efficiency & $1.15(0.24)$ & $0.96(0.13)$ \\
\hline MP efficiency & $0.80(0.04)$ & $0.68(0.04)$ \\
\hline \multicolumn{3}{|l|}{$\mathrm{NE}_{\mathrm{L}}$ pivot $^{2}$} \\
\hline $\mathrm{MJ} / \mathrm{d}$ & $97(19)$ & $97(28)$ \\
\hline Mcal/d & $23.2(4.5)$ & $23.2(6.7)$ \\
\hline $\operatorname{MPpivot}^{2}(\mathrm{~g} / \mathrm{d})$ & $1,382(247)$ & $1,498(424)$ \\
\hline
\end{tabular}

${ }^{1}$ Means of 42 weekly means are presented (43 for DMI and milk yield). Number of cows per treatment was 5 .

${ }^{2} \mathrm{NE}_{\mathrm{L}}$ pivot $=$ level of $\mathrm{NE}_{\mathrm{L}}$ above maintenance supply for which $\mathrm{NE}_{\mathrm{L}}$ efficiency is 1 and $\mathrm{MP}$ efficiency is 0.67 ;

$\mathrm{MPpivot}=$ level of MP above maintenance supply for which MP efficiency is 0.67 and $\mathrm{NE}_{\mathrm{L}}$ efficiency is 1 . 


$$
\mathrm{Y}_{\mathrm{ij}}=\mu+\alpha \mathrm{X}_{\mathrm{ij}}+\varepsilon_{\mathrm{ij}},
$$

where $Y_{i j}$ is the observed milk energy yield, milk fat yield, milk protein yield, and milk lactose yield; $\mu$ is the overall intercept; $\mathrm{X}_{\mathrm{ij}}$ is the corresponding predicted values; $\alpha$ is the overall slope between $\mathrm{Y}$ and $\mathrm{X} ; \varepsilon_{\mathrm{ij}}$ is the residual error; $i$ is the treatment used to calculate the pivot; and $\mathrm{j}$ is the week of lactation. The full model is

$$
\mathrm{Y}_{\mathrm{ijk}}=\mu+\alpha \mathrm{M}_{\mathrm{k}}+\beta \mathrm{L}_{\mathrm{k}}+\left(\lambda+\gamma \mathrm{M}_{\mathrm{k}}+\omega \mathrm{L}_{\mathrm{k}}\right) \mathrm{X}_{\mathrm{ij}}+\varepsilon_{\mathrm{ijk}} .
$$

The difference between model [10] and [11] is that, in the latter, the slope and intercept are allowed to vary between the 3 groups created for stage of lactation. Therefore, $\mu$ is the intercept of the early lactation group; $\alpha$ and $\beta$ are the coefficients adjusting the intercept for mid (M) and late (L) lactation groups, respectively; $\lambda$ is the slope between observed $\mathrm{Y}$ and predicted $\mathrm{X}$ for early lactation; $\gamma$ and $\omega$ are the coefficients adjusting the slope for mid and late lactation groups, respectively; and $\mathrm{k}$ is the stage of lactation. The full model [11] was compared with the reduced model [10] based on the AICc and the RMSE. Differences in AICc $>3$ between the full and reduced models indicate that there is good evidence that the model with the smaller AICc is significantly better than the model with the larger AICc (Burnham and Anderson, 2002).

\section{RESULTS}

Results of the comparison between predicted and observed milk energy yield and milk component yields for the 2 data sets are shown in Table 3. Milk energy yield and milk component yields were predicted with a maximum RMSPE of $13.5 \%$ (for milk fat yield) and a minimum CCC of 0.784 (also for milk fat yield). The slope of the relationships between observed and predicted milk energy yield and milk component yields was within a range of 0.75 and 1.03 , indicating no major slope bias. In fact, the largest part of the prediction error was the random error component (minimum random error was $75.1 \%$ for milk fat yield). This quality of prediction was achieved despite large differences in $\mathrm{MP}$ and $\mathrm{NE}_{\mathrm{L}}$ supply between treatments in data set $1\left[667 \mathrm{~g} / \mathrm{d}\right.$ in $\mathrm{MP}$ and $13 \mathrm{MJ} / \mathrm{d}(3.11 \mathrm{Mcal} / \mathrm{d})$ in $\mathrm{NE}_{\mathrm{L}}$, see Table 1] and in data set $2[513 \mathrm{~g} / \mathrm{d}$ in MP and 29 $\mathrm{MJ} / \mathrm{d}$ (6.93 Mcal/d) in $\mathrm{NE}_{\mathrm{L}}$, see Table 2]. Illustration of the prediction quality is shown in Figure 5 for milk energy yield and milk protein yield of both data sets. Prediction of milk energy yield and milk component yields were predicted with equivalent accuracy between the 2 data sets. However, in the data set from Law et al. (2009), better predictions were achieved for milk energy yield and milk component yields when the pivot was calculated from the high-CP treatment (i.e., $17.3 \%$ $\mathrm{CP}, \mathrm{DM}$ basis) as compared with the low-CP treatment (i.e., $11.4 \% \mathrm{CP}$, DM basis). As an example, milk energy yield was predicted with a CCC of 0.903 and a RMSPE of $5.2 \%$ when the high-CP treatment was used to calculate the pivots, whereas CCC and RMSPE were only 0.689 and $9.6 \%$, respectively, when the low-CP treatment was used to calculate the pivots. This effect was not observed in the data set from Friggens et al. (1998). The full details of the effect of the nutritional treatment used to calculate the pivot can be found in Appendix 3 [Table A3.1 for Law et al. (2009) and Table A3.2 for Friggens et al. (1998)].

The importance of the pivots can be evaluated by comparing the current approach with application of the response curves without any pivot (i.e., assuming the pivot is the observed production). Assessed through the RMSPE and the CCC, the approach using pivot values for $\mathrm{NE}_{\mathrm{L}}$ and MP performed substantially better than the one without pivots (see Table 3 vs. Table A3.3). For data set 1, RMSPE and CCC of milk energy yield and milk component yields were improved by 44 and $29 \%$, respectively, when pivots were used; similarly, in data set 2, RMSPE and CCC were improved by 26 and $8 \%$, respectively. This clearly demonstrates the value of calculating a pivot before applying the response curve.

Based on the AICc, regression models relating pivot-method predicted values to observed values were improved by allowing these models to have different slopes (and intercept) according to stage of lactation (early, mid, and late), indicating significant differences in prediction between groups (see Table 4). However, the effects of stage of lactation were not coherent across data sets. In the data set of Law et al. (2009), for milk protein yield, the slopes were $0.84,0.78$, and 0.62 for early, mid, and late lactation groups, respectively. This indicates less bias in the predicted values for early than late lactation data. This improvement was nevertheless moderate, as the RMSE only decreased from 83 to 81 $\mathrm{g} / \mathrm{d}$ between the reduced and the full model. Similar observations were made for milk energy yield and milk lactose yield, with less bias in predicted values in early and mid lactation as compared with late lactation. Also, for milk energy yield and milk lactose yield, the RMSE decreased only moderately between the reduced and the full model, respectively, from 6.2 to $5.7 \mathrm{MJ} / \mathrm{d}$ (1.48 to $1.36 \mathrm{Mcal} / \mathrm{d})$ and from 123 to $118 \mathrm{~g} / \mathrm{d}$. In the data set of Friggens et al. (1998), the slopes for milk protein yield were $0.72,0.90$, and 0.93 for early, mid, and late lactation groups, respectively. In this case, the 
DANIEL ET AL.

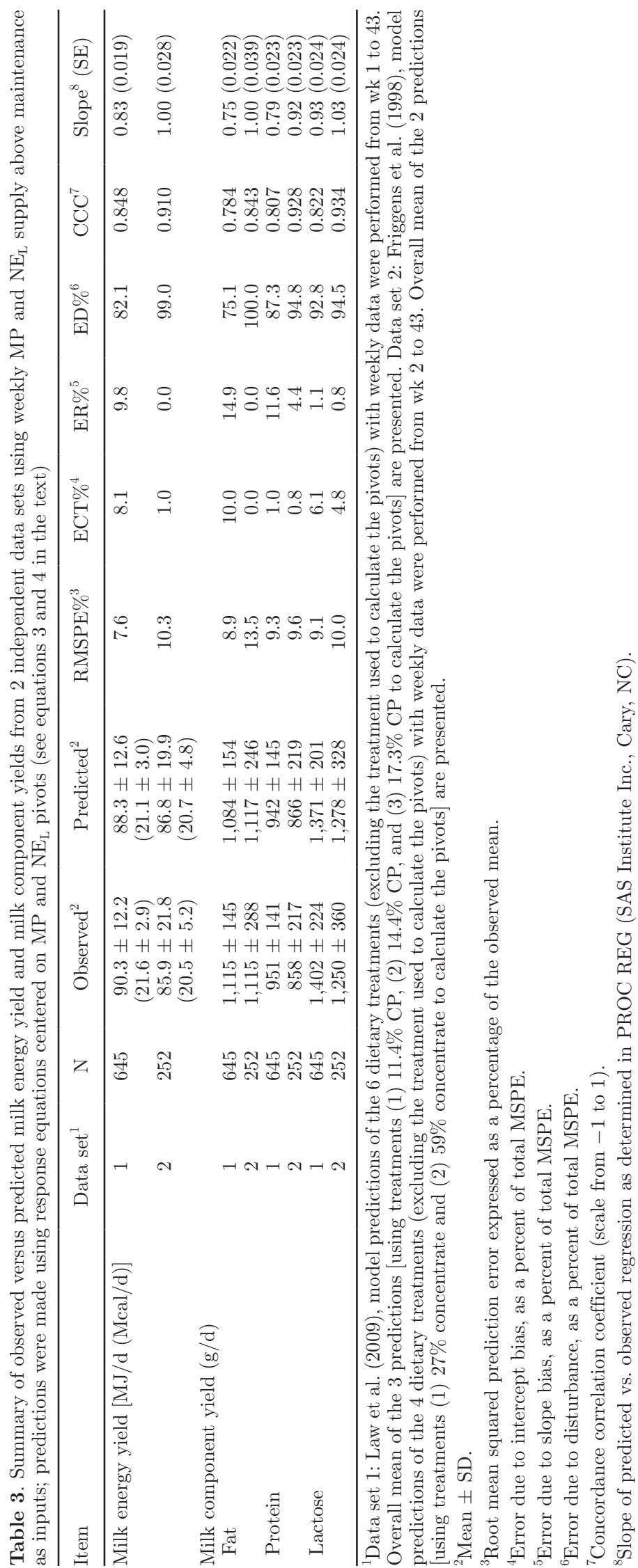


model fit was judged better for mid and late lactation as compared with early lactation. The decrease in RMSE for milk protein yield was larger in this data set, from 81 to $69 \mathrm{~g} / \mathrm{d}$ between the reduced and the full model. This trend was not observed for milk lactose yield, and reduction of RMSE between full and reduced model was minor: 122 to $121 \mathrm{~g} / \mathrm{d}$. In the case of milk fat yield, the slopes indicated better predictions in late lactation as compared with early and mid lactation for both of the data sets (see Table 4).

\section{DISCUSSION}

As demonstrated in Figure 5, the pivot concept can be used to predict milk energy yield and milk compo- nent yields responses to dietary change with RMSPE below $13.5 \%$ and $\mathrm{CCC}$ above 0.784 for diets that are substantially different (Tables 1 and 2) and across all stages of lactation. The 2 data sets used to evaluate the equations in combination with pivot values were very challenging, as there were large differences in the $\mathrm{NE}_{\mathrm{L}}$ and MP supply spectrum, far greater (at least for MP supply) than average differences observed within each experiment used to calibrate the equations. In the original data set (Daniel et al., 2016), those average differences in $\mathrm{MP}$ and $\mathrm{NE}_{\mathrm{L}}$ supply above maintenance were $181 \pm 116 \mathrm{~g} / \mathrm{d}$ and $12 \pm 9 \mathrm{MJ} / \mathrm{d}(2.87 \pm 2.15$ $\mathrm{Mcal} / \mathrm{d}$ ), respectively, whereas in data sets 1 and 2 average differences were $513 \mathrm{~g} / \mathrm{d}$ and $13 \mathrm{MJ} / \mathrm{d}$ (3.11 $\mathrm{Mcal} / \mathrm{d}$ ), respectively. Expressed relative to pivot, the

\section{Friggens et al. (1998)}
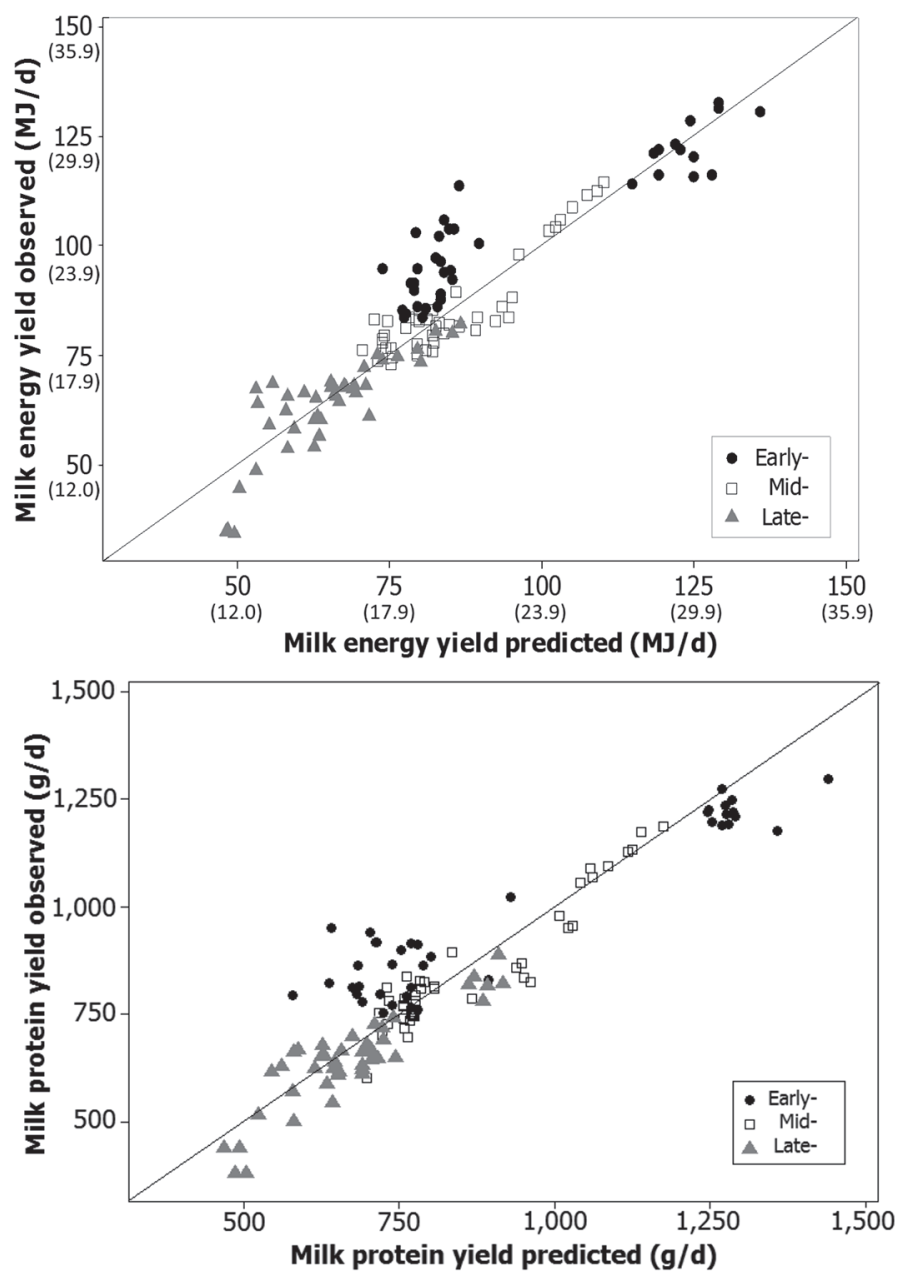

Law et al. (2009)
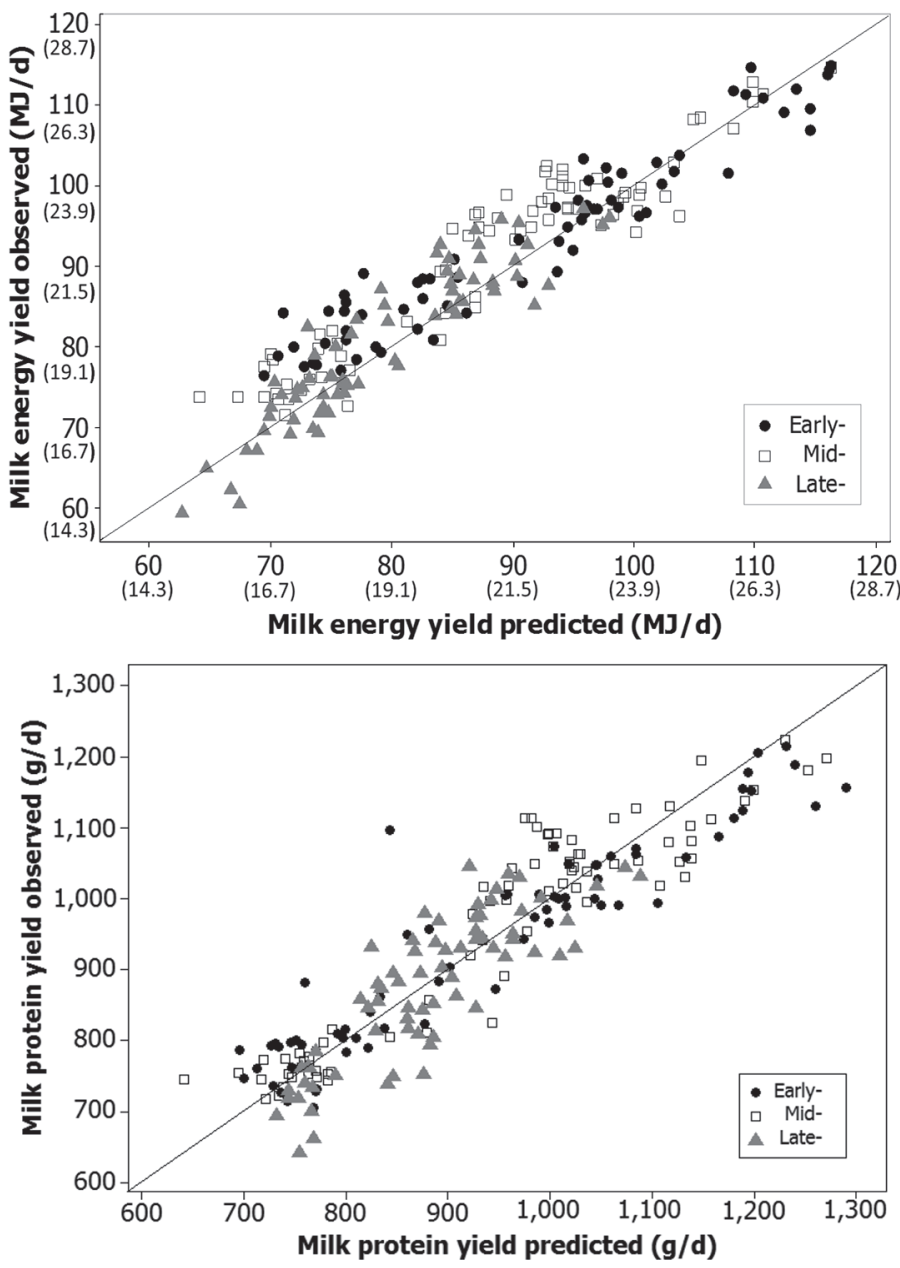

Figure 5. Comparison between observed values of milk yield and milk protein yield and predicted values. The highest quality nutritional treatment in both experiments was used to calculate MPpivot and $\mathrm{NE}_{\mathrm{L}}$ pivot. Equations published in Daniel et al. (2016) were then applied with the calculated pivots to predict values for the other treatments. MPpivot = level of MP above maintenance supply for which MP efficiency is 0.67 and $\mathrm{NE}_{\mathrm{L}}$ efficiency is $1 ; \mathrm{NE}_{\mathrm{L}}$ pivot = level of $\mathrm{NE}_{\mathrm{L}}$ above maintenance supply for which $\mathrm{NE}_{\mathrm{L}}$ efficiency is 1 and $\mathrm{MP}$ efficiency is 0.67 . Each data point represents a treatment mean in a given week of lactation: early lactation $(<100$ DIM, $\bullet$ ), mid lactation $(100<$ DIM $<200, \square)$, and late lactation (>200 DIM, $\mathbf{\Delta})$. In parentheses, energy values are reported in Mcal/d. 
range of MP supply above maintenance in the original data set was between -460 and $368 \mathrm{~g} / \mathrm{d}$ (mean \pm 2 $\mathrm{SD}$ ), whereas this range was between $-1,144$ and 490 $\mathrm{g} / \mathrm{d}$ in data set 1 and between $-1,023$ and $534 \mathrm{~g} / \mathrm{d}$ in data set 2 . With respect to $\mathrm{NE}_{\mathrm{L}}$ supply above maintenance, the original range was between -30 and 30 $\mathrm{MJ} / \mathrm{d}(-7.17$ and $7.17 \mathrm{Mcal} / \mathrm{d})$, whereas this range was between -63 and $27 \mathrm{MJ} / \mathrm{d}(-15.06$ and $5.50 \mathrm{Mcal} / \mathrm{d})$ in data set 1 and between -62 and $42 \mathrm{MJ} / \mathrm{d}(-14.82$ and $10.04 \mathrm{Mcal} / \mathrm{d}$ ) in data set 2. Thus, the equations in combination with the concept of using efficiency pivots appear to be robust even in extreme situations. The concept of using a response curve centered on fixed MPeff and $\mathrm{NE}_{\mathrm{L}}$ eff has emerged from correlations observed between size of expected responses and efficiency, in the context where nutrition is the main driver (Figure 1). This concept was then extrapolated across lactation stages, where $\mathrm{NE}_{\mathrm{L}}$ eff and MPeff are not only influenced by nutrition but also driven by homeorhetic regulation (see Figure 4). The hypothesis was that partitioning of surplus nutrients would be independent of the driving factor, either dietary manipulation or animal physiology. The consequence is that, due to the higher efficiency observed in early lactation as compared with late lactation, responses would be greater in early lactation, consistent with previous work (Broster, 1972; Broster and Thomas, 1981; Kirkland and Gordon, 2001). With this hypothesis, milk energy yield and milk component yields responses were predicted with similar accuracy across stages of lactation (Figure 5 and Table 4). Another implicit consequence of using fixed reference efficiencies to center response equations is that, at a fixed nutrient intake, greater responses are expected for a high-producing as compared with a low-producing cow. This is because, at the same nutrient intake, the lower-producing animal is closer to its maximum capacity of production than the high-producing dairy cow. In agreement with our approach, this effect has previously been observed in a context where cows of different potential are fed at fixed nutrient intake (Brody, 1945; Broster and Thomas, 1981). However, using the pivot (i.e., at same production level relative to potential), low- and high-producing cows are expected to respond to our approach the same way to an increase in nutrient supply. This could explain the divergent conclusion relative to the effect of animal production level on the size of the milk yield response in ad libitum feeding systems (no significant effect: Huhtanen and Nousiainen, 2012; significant effect: Boerman et al., 2015).

Within the large range of data used to calibrate the response equation, no evidence of interaction was found for any of the milk variables (Daniel et al., 2016); thus, the prediction of responses and the calculation of pivots were constructed on this basis. However, difficulties in calculating the pivot values were encountered when the observation was characterized by both high $\mathrm{NE}_{\mathrm{L}}$ eff and

Table 4. Comparison between reduced and full models in AICc, RMSE, and slope of the relationships between observed versus predicted milk energy yield and milk component yields from 2 independent data sets

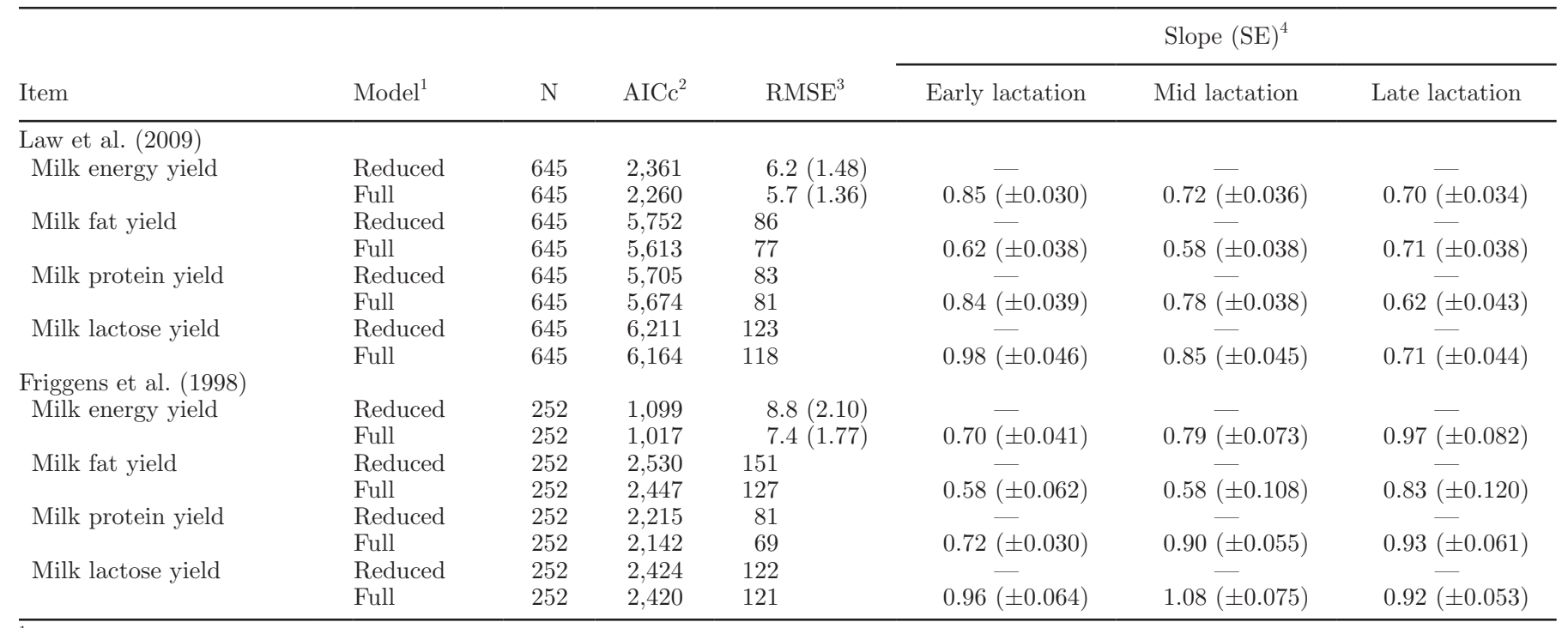

\footnotetext{
${ }^{1}$ Reduced, see equation 10 in the text; full, see equation 11 in the text.

${ }^{2}$ Corrected Akaike's information criterion.

${ }^{3}$ Root mean squared error, expressed in $\mathrm{g} / \mathrm{d}$, except for milk energy yield, in MJ/d and Mcal/d in parentheses.

${ }^{4}$ Slope of the relationship between observed vs. predicted. Early lactation: $<15$ wk in milk; mid lactation: $\geq 15$ to $<30$; late lactation: $\geq 30$ wk in milk.
} 
high MPeff. In these specific conditions, often observed in the first days of the lactation (e.g., Figure 4) or in cases of very poor nutrition, no real solutions for the pivot values were found. Extrapolation of these cases revealed that, in the area of extreme high efficiency for both $\mathrm{NE}_{\mathrm{L}}$ and $\mathrm{MP}$, the milk protein yield response equation can lead to prediction of a positive milk protein yield even when the MP supply above maintenance is zero (depending on $\mathrm{NE}_{\mathrm{L}}$ supply above maintenance). This suggests an interaction between $\mathrm{NE}_{\mathrm{L}}$ and $\mathrm{MP}$ supply, which comes into play when observed $\mathrm{NE}_{\mathrm{L}}$ and $\mathrm{MP}$ supplies are far below their respective pivots (Figure 1) and out of the original range of data used for the calibration of the equations (Daniel et al., 2016). In the present paper, to preserve the simplicity of the pivot method, it was decided to ignore this interaction (i.e., use the original meta-analysis equations of Daniel et al., 2016) and solve the problem of complex numbers through an optimization procedure (detailed in Appendix 2). However, this issue clearly merits further study if the model is to be deployed in relatively extreme situations.

In the current paper, the pivot method was evaluated using group averages, albeit containing small numbers of cows (see Tables 1 and 2). This represents the most common situation, where currently feeding data are available on a group basis. In the context of the increasing development of precision livestock feeding, a next step would be to evaluate the accuracy of this approach when applied at the level of individual cows. Assuming the method is sufficiently accurate, dairy cows within a farm could be ranked based on their estimated production at pivots. This is because the level of production at pivot is adjusted for the effect of nutrition (on an energy and protein basis). Therefore, production at MPeff $=0.67$ and $\mathrm{NE}_{\mathrm{L}}$ eff $=1.00$ is assumed to be standardized, which means that differences in production between animals are assumed not to be due to current nutrition. The ranking of animals generated by this approach would theoretically represent differences in genetics as well as individual difference in permanent environment effects (e.g., past environmental effects).

With respect to predicting responses to change in ration composition under field conditions, the approach presented here is only partly predictive. This is because it uses $\mathrm{NE}_{\mathrm{L}}$ and MP supply as input values, whereas, in practice, they first need to be estimated from the composition of the ration together with a quantification of DMI response to change in ration composition. Therefore, integration of a DMI response equation within this approach is necessary to predict short-term response to change in ration composition under field conditions.

\section{CONCLUSIONS}

This paper provides a method, based on $\mathrm{NE}_{\mathrm{L}}$ and MP efficiency, to estimate the production level of the animal relative to its potential and subsequent milk responses to change in $\mathrm{NE}_{\mathrm{L}}$ and MP supply. This method uses as a pivot the supply of $\mathrm{NE}_{\mathrm{L}}$ and $\mathrm{MP}$, equivalent to $\mathrm{NE}_{\mathrm{L}}$ and MP efficiency of 1 and 0.67 respectively, from which milk energy yield and milk component yields responses can be derived. Independent evaluation using 2 contrasting data sets demonstrated the utility of the pivot concept. Finally, milk energy yield and milk component yields were predicted across lactation stages with RMSPE below $13.5 \%$ and CCC above 0.784 , with a large part of the error due to random variation (above $75.1 \%)$.

\section{ACKNOWLEDGMENTS}

We gratefully acknowledge the work of Rafael Munoz Tamayo (INRA, Paris, France) who developed the optimization procedure used to calculate pivot values on MatLab software (MathWorks, Natick, MA).

\section{REFERENCES}

Andrew, S. M., D. Waldo, and R. Erdman. 1994. Direct analysis of body composition of dairy cows at three physiological stages. J. Dairy Sci. 77:3022-3033.

Bauman, D. E., and W. B. Currie. 1980. Partitioning of nutrients during pregnancy and lactation: A review of mechanisms involving homeostasis and homeorhesis. J. Dairy Sci. 63:1514-1529.

Belyea, R., G. Frost, F. Martz, J. Clark, and L. Forkner. 1978. Body composition of dairy cattle by potassium-40 liquid scintillation detection. J. Dairy Sci. 61:206-211.

Bibby, J., and H. Toutenburg. 1977. Prediction and Improved Estimation in Linear Models. Wiley, Berlin, Germany.

Boerman, J. P., S. Potts, M. VandeHaar, M. Allen, and A. Lock. 2015. Milk production responses to a change in dietary starch concentration vary by production level in dairy cattle. J. Dairy Sci. 98:4698-4706.

Brody, S. 1945. Bioenergetics and Growth, with Special Reference to the Efficiency Complex in Domestic Animals. Reinhold, New York, NY.

Broster, W. 1972. Effect on milk yield of the cow of the level of feeding during lactation. Dairy Sci. Abstr. 34:265-288.

Broster, W. and C. Thomas. 1981. Influence of level and pattern of concentrate input on milk output. Pages 49-69 in Recent Advances in Animal Nutrition. W. Haresign and D. J. A. Cole, ed. Butterworths, London, UK.

Brun-Lafleur, L., L. Delaby, F. Husson, and P. Faverdin. 2010. Predicting energy $\times$ protein interaction on milk yield and milk composition in dairy cows. J. Dairy Sci. 93:4128-4143.

Burnham, K. P., and D. R. Anderson. 2002. Model Selection and Multimodel Inference. 2nd ed. Springer Verlag, New York City, NY.

Chilliard, Y., M. Cisse, R. Lefaivre, and B. Remond. 1991. Body composition of dairy cows according to lactation stage, somatotropin treatment, and concentrate supplementation. J. Dairy Sci. 74:3103-3116.

Daniel, J. B., N. Friggens, P. Chapoutot, H. Van Laar, and D. Sauvant. 2016. Milk yield and milk composition responses to change in 
predicted net energy and metabolizable protein: a meta-analysis. Animal 10:1975-1985.

Friggens, N. C., G. Emmans, I. Kyriazakis, J. Oldham, and M. Lewis. 1998. Feed intake relative to stage of lactation for dairy cows consuming total mixed diets with a high or low ratio of concentrate to forage. J. Dairy Sci. 81:2228-2239.

Friggens, N. C., P. Berg, P. Theilgaard, I. R. Korsgaard, K. L. Ingvartsen, P. Løvendahl, and J. Jensen. 2007. Breed and parity effects on energy balance profiles through lactation: Evidence of genetically driven body energy change. J. Dairy Sci. 90:5291-5305.

Gibb, M., W. Ivings, M. Dhanoa, and J. Sutton. 1992. Changes in body components of autumn-calving Holstein-Friesian cows over the first 29 weeks of lactation. Anim. Prod. 55:339-360.

Huhtanen, P., and J. Nousiainen. 2012. Production responses of lactating dairy cows fed silage-based diets to changes in nutrient supply. Livest. Sci. 148:146-158.

Jensen, C., S. Østergaard, I. Schei, J. Bertilsson, and M. R. Weisbjerg. 2015. A meta-analysis of milk production responses to increased net energy intake in Scandinavian dairy cows. Livest. Sci. 175:59-69.

Kirkland, R. M., and F. Gordon. 2001. The effects of milk yield and stage of lactation on the partitioning of nutrients in lactating dairy cows. J. Dairy Sci. 84:233-240.

Komaragiri, M. V., D. Casper, and R. Erdman. 1998. Factors affecting body tissue mobilization in early lactation dairy cows. 2. Effect of dietary fat on mobilization of body fat and protein. J. Dairy Sci. $81: 169-175$.

Komaragiri, M. V., and R. A. Erdman. 1997. Factors affecting body tissue mobilization in early lactation dairy cows. 1. Effect of dietary protein on mobilization of body fat and protein. J. Dairy Sci. 80:929-937.

Lagarias, J. C., J. A. Reeds, M. H. Wright, and P. E. Wright. 1998 Convergence properties of the Nelder-Mead simplex method in low dimensions. SIAM J. Optim. 9:112-147.

Law, R. A., F. Young, D. Patterson, D. Kilpatrick, A. Wylie, and C. Mayne. 2009. Effect of dietary protein content on animal production and blood metabolites of dairy cows during lactation. J. Dairy Sci. 92:1001-1012.

Leclerc, H. 2008. Development of the French dairy cattle test-day model genetic evaluation and prospects of using results for herd management. Ph.D. Thesis. AgroParisTech, Paris, France.

Lin, L. I. K. 1989. A concordance correlation coefficient to evaluate reproducibility. Biometrics 45:255-268.

Martin, R. A., and F. Ehle. 1986. Body composition of lactating and dry Holstein cows estimated by deuterium dilution. J. Dairy Sci. 69:88-98

McGuffey, R. K., R. Basson, and T. Spike. 1991. Lactation response and body composition of cows receiving somatotropin and three ratios of forage to concentrate. J. Dairy Sci. 74:3095-3102.

NRC. 2001. Nutrient Requirements of Dairy Cattle. 7th rev. ed. Natl. Acad. Press, Washington, DC.

Neal, H. D. S. C., and J. H. M. Thornley. 1983. The lactation curve in cattle: A mathematical model of the mammary gland. J. Agric. Sci. (Camb.) 101:389-400.

Sauvant, D., G. Cantalapiedra-Hijar, L. Delaby, J. Daniel, P. Faverdin, and P. Nozière. 2015a. Actualisation des besoins protéiques des ruminants et détermination des réponses des femelles laitières aux apports de protéines digestibles dans l'intestin. INRA Prod. Anim. $28: 347-368$.

Sauvant, D., and P. Nozière. 2016. Quantification of the main digestive processes in ruminants: The equations involved in the renewed energy and protein feed evaluation systems. Animal 10:755-770.

Sauvant, D., I. Ortigues-Marty, S. Giger-Reverdin, and P. Nozière. 2015b. Actualisation des besoins et efficacités énergétiques des femelles laitières. Renc. Rech. Ruminants 22:225-228.

Tamminga, S., P. Luteijn, and R. Meijer. 1997. Changes in composition and energy content of liveweight loss in dairy cows with time after parturition. Livest. Prod. Sci. 52:31-38.

Theil, H. 1966. Applied Economic Forecasting. North-Holland Publishing Company, Amsterdam, the Netherlands.
Thomas, C. 2004. Feed Into Milk: A New Applied Feeding System for Dairy Cows. Nottingham University Press, Nottingham, UK.

Vetharaniam, I., S. R. Davis, M. Upsdell, E. S. Kolver, and A. B. Pleasants. 2003. Modeling the effect of energy status on mammary gland growth and lactation. J. Dairy Sci. 86:3148-3156.

Volden, H. 2011. NorFor-The Nordic feed evaluation system. EAAP Publications No 130. Wageningen Academic Publishers, the Netherlands.

\section{APPENDIX 1}

\section{Energy Calculations}

Milk energy $(\mathrm{MJ} / \mathrm{d})=39.8 \times \mathrm{MFY}+23.9 \times \mathrm{MPY}$ $+16.5 \times$ MLY, where MFY $(\mathrm{kg} / \mathrm{d})=$ milk fat yield, MPY $(\mathrm{kg} / \mathrm{d})=$ milk protein yield, and MLY $(\mathrm{kg} / \mathrm{d})=$ milk lactose yield.

$\mathrm{NE}_{\mathrm{L}}$ supply $(\mathrm{MJ} / \mathrm{d})=\mathrm{DMI}(\mathrm{kg} / \mathrm{d}) \times \mathrm{NE}_{\mathrm{L}}$, where $\mathrm{NE}_{\mathrm{L}}(\mathrm{MJ} / \mathrm{kg}$ of $\mathrm{DM})=$ dietary $\mathrm{NE}_{\mathrm{L}}$ content.

$\mathrm{NE}_{\mathrm{L}}$ maintenance $(\mathrm{MJ} / \mathrm{d})=0.394 \times \operatorname{avgBW}^{0.75}$, where avgBW $(\mathrm{kg})=$ average BW of the lactation.

$\mathrm{NE}_{\mathrm{L}}$ gestation $(\mathrm{MJ} / \mathrm{d})=7.1 \times[0.00072 \times 45 \times$ $e^{(0.116 \times \mathrm{WIP})}$, where 7.1 converts UFL (French energy unit for milk) into MJ; WIP = week in pregnancy. The calf $\mathrm{BW}$ at birth was assumed to be $45 \mathrm{~kg}$ and all animals were assumed pregnant at wk 14 of lactation.

$\mathrm{NE}_{\mathrm{L}}$ above maintenance $(\mathrm{MJ} / \mathrm{d})=\mathrm{NE}_{\mathrm{L}}$ supply $\left(\mathrm{NE}_{\mathrm{L}}\right.$ maintenance $+\mathrm{NE}_{\mathrm{L}}$ gestation $)$.

$\mathrm{EB}(\mathrm{MJ} / \mathrm{d})=\left[\mathrm{NE}_{\mathrm{L}}\right.$ supply $-\left(\right.$ Milk energy $+\mathrm{NE}_{\mathrm{L}}$ maintenance $+\mathrm{NE}_{\mathrm{L}}$ gestation) $] / \mathrm{k}_{\mathrm{ls}} \times \mathrm{k}_{\mathrm{gt}}$, where $\mathrm{EB}=$ energy balance; $\mathrm{k}_{\mathrm{ls}}$ is the efficiency to convert dietary $\mathrm{ME}$ into milk $\mathrm{NE}_{\mathrm{L}}$ calculated as $\mathrm{k}_{\mathrm{ls}}=0.65+0.247 \times$ [(ME/GE) - 0.63], with $\mathrm{ME}=$ metabolizable energy and $\mathrm{GE}=$ gross energy; $\mathrm{k}_{\mathrm{gt}}$ is the efficiency to convert $\mathrm{NE}_{\mathrm{L}}$ from body reserves into milk $\mathrm{NE}_{\mathrm{L}}$ and also to convert dietary $\mathrm{ME}$ into $\mathrm{NE}_{\mathrm{L}}$ body reserves. The coefficient $\mathrm{k}_{\mathrm{gt}}$ is calculated as $\mathrm{k}_{\mathrm{gt}}=\mathrm{k}_{\mathrm{ls}}+0.15$.

\section{Protein Calculations}

Fecal metabolic CP losses $(\mathrm{g} / \mathrm{d})=$ DMI $(\mathrm{kg} / \mathrm{d}) \times$ $[5 \times(0.57+0.0074 \times$ OMnd $)]$, where OMnd $(\mathrm{g} / \mathrm{kg}$ of $\mathrm{DM})=$ organic matter non-digested.

Urinary endogenous $\mathrm{N}$ losses $(\mathrm{g} / \mathrm{d})=0.312 \times$ avgBW , where avgBW $(\mathrm{kg})=$ average BW of the lactation.

Scurf CP losses $(\mathrm{g} / \mathrm{d})=0.2 \times \operatorname{avgBW}^{0.6}$, with avgBW $(\mathrm{kg})=$ average $\mathrm{BW}$ of the lactation.

$\mathrm{BPB}(\mathrm{g} / \mathrm{d})=\left[21.2+56.04 \times e^{(-0.033 \times \mathrm{DIM})}\right] \times$ $(\mathrm{EB} / 7.37)$, where $\mathrm{BPB}=$ body protein balance, and $\mathrm{EB}=$ energy balance.

MP supply $(\mathrm{g} / \mathrm{d})=\mathrm{DMI}(\mathrm{kg} / \mathrm{d}) \times \mathrm{MP}$, where MP $(\mathrm{g} / \mathrm{kg}$ of $\mathrm{DM})=$ dietary MP content.

MP gestation $(\mathrm{g} / \mathrm{d})=\left[0.07 \times 45 \times e^{(0.111 \times \text { WIP })}\right] \times$ 0.64 , where WIP $=$ week in pregnancy. The calf $\mathrm{BW}$ 
was assumed to be $45 \mathrm{~kg}$ and all animals were assumed pregnant at wk 14 of lactation. The coefficient 0.64 converts MP requirement for gestation into MP utilized for gestation.

MP efficiency, BPB requirement and MP above maintenance supply are calculated iteratively by using an initial value of 0.67 .

1. $\mathrm{BPB}$ requirement $(\mathrm{g} / \mathrm{d})=$ if $\mathrm{EB}<0$, then $\mathrm{BPB}$ $\times \mathrm{MP}$ efficiency, if $\mathrm{EB}>0$ then $\mathrm{BPB} / \mathrm{MP}$ efficiency.

2. MP above maintenance $(\mathrm{g} / \mathrm{d})=\mathrm{MP}$ supply (Fecal metabolic CP losses/MP efficiency) Urinary endogenous N losses - (Scurf CP losses/ MP efficiency) - BPB requirement - (MP gestation/MP efficiency).

3. $\mathrm{MP}$ efficiency $=$ Milk protein yield/MP above maintenance.

4. Steps 1 to 3 were repeated 20 times using MP efficiency calculated in step 3.

\section{APPENDIX 2}

Our mathematical approach aimed to solve the following equations:

$$
\begin{gathered}
\mathrm{E}_{1}: \text { MPpivot } \times 0.67-\mathrm{MPY}+0.19 \\
\times(\mathrm{MP}-\mathrm{MPpivot})-0.000193 \\
\times(\mathrm{MP}-\mathrm{MPpivot})^{2}+3.137 \times\left(\mathrm{NE}_{\mathrm{L}}-\mathbf{N E}_{\mathbf{L}} \text { pivot }\right) \\
-0.021 \times\left(\mathrm{NE}_{\mathrm{L}}-\mathbf{N E}_{\mathrm{L}} \text { pivot }\right)^{2}=0, \text { and } \\
\mathrm{E}_{2}: \mathbf{N E}_{\mathbf{L}} \text { pivot }-\mathrm{MEY}+0.015 \times(\mathrm{MP}-\mathbf{M P p i v o t}) \\
-0.000017 \times(\mathrm{MP}-\mathbf{M P p i v o t})^{2}+0.166 \\
\times\left(\mathrm{NE}_{\mathrm{L}}-\mathrm{NE}_{\mathbf{L}} \mathbf{p i v o t}\right)-0.0018 \\
\times\left(\mathrm{NE}_{\mathrm{L}}-\mathbf{N E}_{\mathbf{L}} \text { pivot }\right)^{2}=0,
\end{gathered}
$$

where MP is the MP above maintenance supply (g/d), $\mathrm{NE}_{\mathrm{L}}$ is the $\mathrm{NE}_{\mathrm{L}}$ above maintenance supply (MJ/d),
MPY is the milk protein yield $(\mathrm{g} / \mathrm{d}), \mathrm{MEY}$ is the milk energy yield (MJ/d), MPpivot is the level of MP above maintenance supply for which MP efficiency is 0.67 $(\mathrm{g} / \mathrm{d})$, and $\mathrm{NE}_{\mathrm{L}}$ pivot is the level of $\mathrm{NE}_{\mathrm{L}}$ above maintenance supply for which $\mathrm{NE}_{\mathrm{L}}$ efficiency is $1(\mathrm{MJ} / \mathrm{d})$. Metabolizable protein, $\mathrm{NE}_{\mathrm{L}}, \mathrm{MPY}$ and $\mathrm{MEY}$ are given as input and $\mathrm{NE}_{\mathrm{L}}$ pivot and MPpivot are the variables to be found to satisfy $\mathrm{E}_{1}$ and $\mathrm{E}_{2}$.

To solve these equations the symbolic toolbox of Matlab (MathWorks, Natick, MA) was used. Due to the nature of the equations (2 quadratic effects within each equation), there are 4 combination of values for $\mathrm{NE}_{\mathrm{L}}$ pivot and MPpivot. These values were obtained by using the Matlab function solve, which provides symbolic solutions for algebraic equations. When evaluating numerically the 4 couples of solutions obtained, 2 give systematically complex numbers and were discarded. Between the 2 real solutions, the chosen solution was the one with smaller differences between MP and MPpivot and between $\mathrm{NE}_{\mathrm{L}}$ and $\mathrm{NE}_{\mathrm{L}}$ pivot.

When applying the symbolic derived solutions to a large database of the literature (1,299 treatment means), all 4 solutions had complex numbers in $19.3 \%$ of the cases. When the 4 solutions contained complex numbers, it was then decided to calculate the pivot values by setting an optimization problem that minimizes the following cost function $F$

$$
F=\left|\mathrm{E}_{1}\right|+10.716 \times\left|\mathrm{E}_{2}\right| .
$$

The value of 10.716 is a weighting coefficient to express the errors equivalently by considering the units of $E_{1}$ and $\mathrm{E}_{2}$. This coefficient was calculated from original root mean square error of $\mathrm{E}_{1}$ and $\mathrm{E}_{2}(31.4 / 2.93$; Daniel et al., 2016).

The optimization procedure was performed in Matlab by the function fminsearch, which uses an algorithm of optimization the Nelder-Mead method (Lagarias et al., 1998). 


\section{APPENDIX 3}

Table A3.1. Summary of observed versus predicted milk energy yield and milk component yields from the data set of Law et al. (2009) using weekly $\mathrm{MP}$ and $\mathrm{NE}_{\mathrm{L}}$ supply above maintenance as inputs; predictions were made using response equations centered on $\mathrm{MP}$ and $\mathrm{NE}_{\mathrm{L}}$ pivots (see equations 3 and 4 in the text)

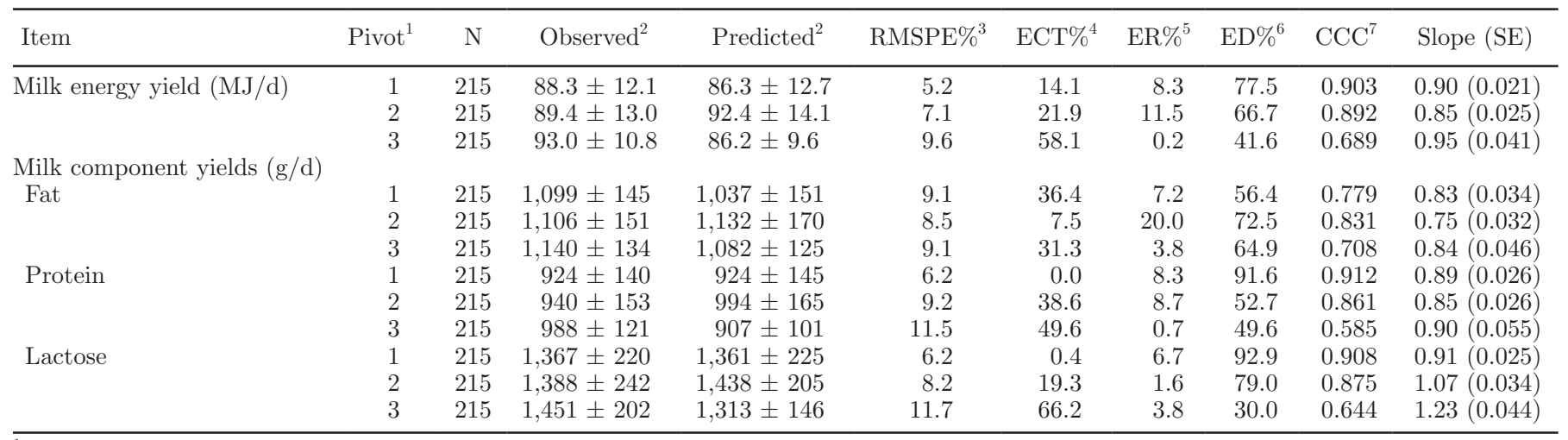

${ }^{1}$ Pivot 1: Pivots were calculated using the dietary treatment with $17.3 \% \mathrm{CP}$ over the whole lactation. The model predictions for the 5 other dietary treatments with weekly data were performed from wk 1 to 43 . Pivot 2: Pivots were calculated using the dietary treatment with $14.4 \%$ $\mathrm{CP}$ over the whole lactation. The model predictions for the 5 other dietary treatments with weekly data were performed from wk 1 to 43 . Pivot 3: Pivots were calculated using the dietary treatment with $11.4 \% \mathrm{CP}$ over the whole lactation. The model predictions for the 5 other dietary treatments with weekly data were performed from wk 1 to 43.

${ }^{2}$ Mean \pm SD.

${ }^{3}$ Root mean squared prediction error expressed as a percentage of the observed mean.

${ }^{4}$ Error due to intercept bias, as a percent of total MSPE.

${ }^{5}$ Error due to slope bias, as a percent of total MSPE.

${ }^{6}$ Error due to disturbance, as a percent of total MSPE.

${ }^{7}$ Concordance correlation coefficient (scale from -1 to 1 ).

${ }^{8}$ Slope of predicted vs. observed regression as determined in PROC REG (SAS Institute Inc., Cary, NC).

Table A3.2. Summary of observed versus predicted milk energy yield and milk component yields from the data set of Friggens et al. (1998) using weekly $\mathrm{MP}$ and $\mathrm{NE}_{\mathrm{L}}$ supply above maintenance as inputs. Predictions were made using response equations centered on $\mathrm{MP}$ and $\mathrm{NE} \mathrm{L}_{\mathrm{L}}$ pivots (see equations 3 and 4 in the text)

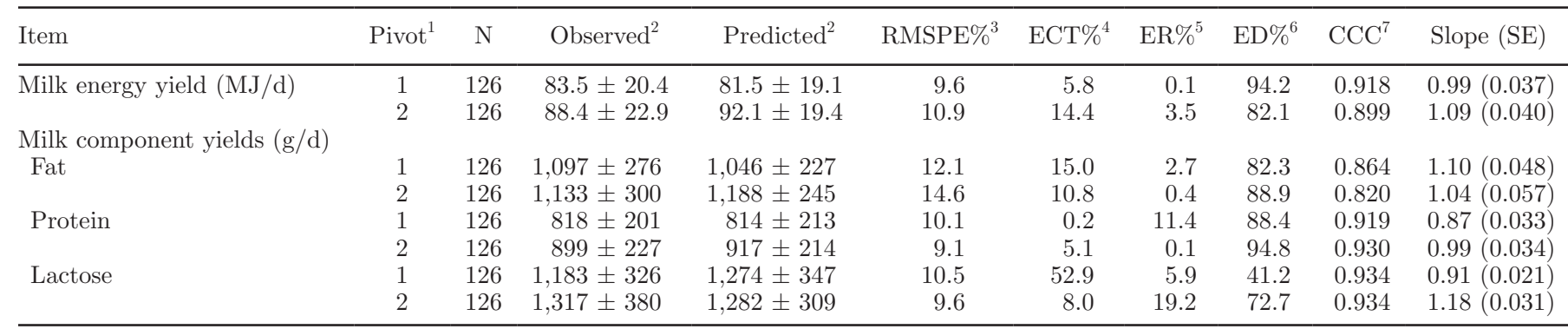

${ }^{1}$ Pivot 1: Pivots were calculated using the dietary treatment with $59 \%$ concentrate over the whole lactation. The model predictions for the 3 other dietary treatments with weekly data were performed from wk 2 to 43 . Pivot 2 : Pivots were calculated using the dietary treatment with $27 \%$ concentrate over the whole lactation. The model predictions for the 3 other dietary treatments with weekly data were performed from wk 2 to 43 .

${ }^{2}$ Mean \pm SD.

${ }^{3}$ Root mean squared prediction error expressed as a percentage of the observed mean.

${ }^{4}$ Error due to intercept bias, as a percent of total MSPE.

${ }^{5}$ Error due to slope bias, as a percent of total MSPE.

${ }^{6}$ Error due to disturbance, as a percent of total MSPE.

${ }^{7}$ Concordance correlation coefficient (scale from -1 to 1 ).

${ }^{8}$ Slope of predicted vs. observed regression as determined in PROC REG (SAS Institute Inc., Cary, NC). 
Table A3.3. Summary of observed versus predicted milk energy yield and milk component yields from 2 independent data sets using weekly MP and $\mathrm{NE}_{\mathrm{L}}$ supply above maintenance as inputs; weekly predictions were made using response equations centered on $\mathrm{MP}$ and $\mathrm{NE} \mathrm{L}_{\mathrm{L}}$ supply above maintenance of one of the treatments (i.e., application of the response equations without any pivot)

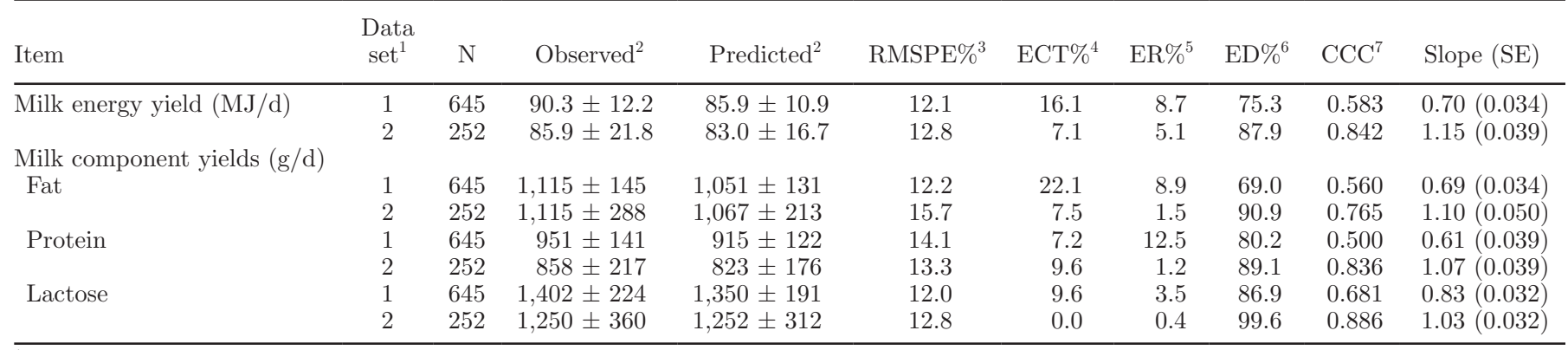

${ }^{1}$ Data set 1: Law et al. (2009), model predictions of the 6 dietary treatments (excluding the treatment used to center the equation) with weekly data were performed from wk 1 to 43 . Overall means of the 3 predictions [using treatments (1) $11.4 \% \mathrm{CP},(2) 14.4 \% \mathrm{CP}$, and (3) $17.3 \% \mathrm{CP}$ to center the equation] are presented. Data set 2: Friggens et al. (1998), model predictions of the 4 dietary treatments (excluding the treatment used to calculate the pivots) with weekly data were performed from wk 2 to 43 . Overall means of the 2 predictions [using treatments (1) $27 \%$ concentrate and (2) 59\% concentrate to calculate the pivots] are presented.

${ }^{2}$ Mean \pm SD.

${ }^{3}$ Root mean squared prediction error expressed as a percentage of the observed mean.

${ }^{4}$ Error due to intercept bias, as a percent of total MSPE.

${ }^{5}$ Error due to slope bias, as a percent of total MSPE.

${ }^{6}$ Error due to disturbance, as a percent of total MSPE.

${ }^{7}$ Concordance correlation coefficient (scale from -1 to 1 ).

${ }^{8}$ Slope of predicted vs. observed regression as determined in PROC REG (SAS Institute Inc., Cary, NC). 